\title{
Heparin Interaction with Protein-Adsorbed Surfaces ${ }^{1}$
}

\author{
LYNN C. WINTERTON,*,2 JOSEPH D. ANDRADE,* JAN FEIJEN, $;$ \\ AND SUNG WAN KIM ${ }^{3}$ \\ *Department of Materials Science and Engineering, $\dagger$ Department of Pharmaceutics, University of Utah, \\ Salt Lake City, Utah 84112; and $\$$ Department of Chemical Technology, Twente \\ University of Technology, 7500AE Enschede, The Netherlands
}

Received October 9, 1985; accepted February 6, 1986

\begin{abstract}
Albumin and fibrinogen show no binding affinity to varied molecular weights of heparin at physiological pH. Human plasma fibronectin was shown to bind heparins in both the solution and adsorbed states. Fibronectin was shown to have six active binding sites for heparins which may be sterically blocked in some adsorbed states. ${ }^{125}$ I-Fibronectin monolayer concentrations were shown to be significantly different on polyvinyl chloride surfaces when compared to hydrophilic/hydrophobic silica, Biomer, Silastic, and polystyrene surfaces. Preadsorbing fibronectin to various substrates and then allowing heparins to interact with the protein monolayer made it possible to bind up to $0.2 \mu \mathrm{g} / \mathrm{cm}^{2}$ heparin in a plasma environment. This fibronectin-heparin complex was at least $85 \%$ stable in plasma and buffer solutions for up to $8 \mathrm{~h}$ time. The complex was observed to prolong blood clotting times two to three times over that of controls as assayed by Activated Partial Thromboplastin Times. All of the bound heparin was observed to be active by its ability to bind Factor $X_{a}$ in plasma. Monolayers of blood proteins adsorbed from human serum were not observed to be active in binding heparins. The fibronectin-heparin conjugate showed low activation of blood components compared to protein monolayers preadsorbed from human sera as assayed by Activated Partial Thromboplastin Time. (๑) 1986 Academic Press, Inc.
\end{abstract}

\section{INTRODUCTION}

Great advances have been made during the past decade toward the concept of rendering biomaterials nonthrombogenic $(1,2)$. It has been proposed that relationships exist between the blood compatibility of foreign substrates and substrate characteristics, such as surface charge, hydrophilicity, surface-free energy, and surface protein interactions (3). Probably the most important unresolved problem with blood-contacting devices is that these devices are not as biologically compatible (inactive) with blood as blood is with the endothelial lin-

\footnotetext{
${ }^{1}$ Presented at the 5th International Conference on Surface and Colloid Science, Clarkson University, Potsdam, N.Y., June 24-26, 1985, as part of a symposium entitled Protein and Polyelectrolyte Adsorption.

${ }^{2}$ Current address: Ciba-Geigy Corporation, $2910 \mathrm{Am}-$ wiler Court, Atlanta, Georgia 30360.

${ }^{3}$ To whom all correspondence should be addressed.
}

ing of the vessels. When blood contacts medical devices or foreign surfaces, surface activation of the blood components occurs. Uninterrupted, thrombosis will follow.

Several areas of intense research exist as to how to most effectively render a blood-containing surface nonthrombogenic. These include blood compatibility via: (a) mutually compatible moduli of the implant (medical device) and the surrounding tissue so as not to traumatize the blood (4); (b) controlling the concentration and species of the adsorbed proteinaceous monolayer; (c) stopping platelet adhesion, retention, and/or degranulation following adhesion; and (d) stopping fibrin formation or destroying the crosslinked fibrin clot superstructure. Researchers using the approaches of (b) or (c) have shown that albuminated surfaces or surfaces with an abundance of albumin preferentially adsorbed to them tend to be less thrombogenic than those 
with a relative abundance of absorbed fibrinogen or gamma-globulin $(\gamma$-globulin) $(3,5-$ 7). In these studies, platelet adherence to adsorbed albumin and other adsorbed nonglycoproteins did not occur, due possibly to a lack of carbohydrate moieties, which are plentiful in fibrinogen and $\gamma$-globulins (8). Platelet adhesion and the resultant morphological changes seem to be determined both by the composition and the conformation of the initially adsorbed protein monolayer (9). The preferential adsorption of albumin, or maintenance of a preadsorbed albumin monolayer requires that implanted surfaces be passive to most proteins yet "recognize" albumin and bind to it (10). This usually requires surface modification since most surfaces do not preferentially adsorb albumin (11-15).

Methodology (a) above is unique in that it ignores most of the surface effects associated with blood-containing devices and instead focuses upon the bulk properties of the substrate to inhibit surface-induced thrombosis. The hypothesis is that moduli differences are what the body responds to in the activation of the intrinsic coagulation pathway. This methodology, like (b), requires new or modified materials to obtain the required bulk and surface characteristics.

The methodologies listed in (c) and (d) are accomplished by inhibiting platelet adhesion and aggregation and fibrin formation via pharmaceutical approaches. Using platelet and coagulation inhibitors, in conjunction with the medical devices, it is possible to improve blood compatibility by blocking the inherent mechanisms that are the driving force for these normal physiological functions. However, systemic usage of these inhibitors at physiologically necessary concentrations could prove fatal; i.e., vascular hemorrhage would remain unchecked by both coagulation or platelet adhesion. Recognition of this problem has resulted in several unique and innovative approaches for local delivery of small doses of either platelet inhibitors, coagulation inhibitors, or both, in concentrations too low to have bulk effect (16). The most prevalent drug being currently delivered in this fashion is heparin. However, prostaglandins and urokinase (17) have also been utilized successfully for their antiplatelet and fibrinolytic activities, respectively.

A novel approach by Henninck et al. (18) to evaluate both antiplatelet activity and anticoagulation has been made utilizing the natural driving force of protein adsorption to decrease surface-free energy. Heparin is delivered onto a medical device using the protein which itself reduces platelet adhesion (7, 19-21). In this methodology, heparin is covalently bound to albumin and preadsorbed to implantable polymers. The albumin coverage inhibits platelet adhesion and retention on the substrate surface while the immobilized heparin inactivates the coagulation cascade on a localized level.

Using this last approach as a type model, it may be possible to improve upon it by preadsorbing blood proteins, that have a natural affinity to heparin, onto medical grade materials. Heparin is then bound to the adsorbed protein monolayer in sufficient quantity to cause a localized inhibition of the coagulation cascade and a resultant depressed platelet response. The advantages of this technique are several fold: (i) there is no compromising of the heparin or protein structure by covalently altering either one; (ii) there is no compromising of the substrate surface or extended chemistries to covalently link the heparin or protein to the surface of interest; (iii) the adoption of a "naturally" occurring physiological phenomenon; (iv) no toxicological side effects from extraneous chemical reactions; (v) no chemical modification of the surface of interest-this allows for choices of materials with desirable mechanical properties without worrying about needed preferential adsorption of specific proteins; and (vi) ease of preparation. In case (iii) the naturally occurring adsorption of serum proteins is used to reduce the surface energy of a blood-contacting medical device followed by affinity binding of heparin to the protein. This process (iii) and resultant protein-heparin ligand may not be physiologically viewed as 
an antigen thereby having antibodies produced against it.

\section{MATERIALS AND METHODS}

Biomer (Ethicon Inc., Somerville, N.J.) was received as a $30 \%$ by weight (w/v) solution in $N, N$-dimethylacetamide (DMAC). The solution was diluted to a $15 \%(\mathrm{w} / \mathrm{v})$ solution in DMAC (Baker Chemical, Phillipsburg, N.J.) and precipitated in distilled water. The polymer precipitate was thoroughly washed, dried, and vacuum-dessicated for $12 \mathrm{~h}$ at room temperature. The dried polymer precipitate was stored in the dark, at room temperature, in a dry glass container. This polymer precipitate was the stock of Biomer for the entire study.

Polyvinyl chloride (Bentley Laboratory Inc., Irvine, Calif.) was supplied in the form of "Implant-Tested" cardiovascular bypass tubing. Upon receipt, the tubing was stripped of all inked impressions by cutting those sections out and discarding them. The remainder was cut into small pieces and stored in the dark in a dry glass container at room temperature.

Polystyrene (Corning Glass, Corning, N.Y.) was supplied as sterile culture dishes or as 1.00 $\mathrm{mm}$ spherical beads (Sinclair-Koppers Co.). Polystyrene (PS) was chosen as a reference material due to its chemical similarity to pure $\mathrm{PVC}$ and since it is available in relatively large pure quantities. The PS beads were used as received, whereas the culture dishes were granularized and stored in the dark in dry glass containers at room temperature.

Polydimethylsiloxane (PDMSO) was supplied as nonreinforced medical grade subdermal implant Silastic sheeting or as Medical Adhesive 891 (both from Dow Corning Corp., Midland, Mich.). PDMSO was chosen because of its current usage in the biomedical field as a common subdermal implant material. PDMSO, of which Silastic is a type, is also a reference material of the National Heart, Lung and Blood Institute (22).

Fused amorphous silica microscope slides and glass beads, 1.00 to $1.05 \mathrm{~mm}$ diameter (B. Braun Melsunger, Apperatebau), were utilized as reference hydrophilic substrates. The chemical composition of these glass beads has been determined elsewhere (23). The chemical composition of the fused amorphous silica was considered to be $100 \% \mathrm{SiO}_{2}$ and was verified via $\mathrm{X}$-ray photoelectron spectroscopy.

Serum albumin (human, Fraction V) was obtained from Sigma Chemicals, St. Louis, Mo. (A-2376). The albumin was stored dessicated at $0^{\circ} \mathrm{C}$. No further purification or chemical alteration was made to the albumin.

Fibrinogen (bovine, 95\% clottable) was obtained from Miles Laboratories, Elkhart, Indiana (Pentex R, Lot 28) and stored dessicated at $-20^{\circ} \mathrm{C}$. No further purification or chemical alteration was attempted.

Human plasma fibronectin was supplied frozen $\left(-80^{\circ} \mathrm{C}\right)$ in Tris buffer $(\mathrm{pH} \mathrm{7.4)}$ in 1$\mathrm{ml}$ aliquots as a generous gift from Dr. Deane F. Mosher (Department of Hematology, University of Wisconsin). The fibronectin was stored at $-80^{\circ} \mathrm{C}$ until used.

Sodium heparin derived from porcine intestinal mucosa was obtained from Diosynth Inc., Chicago, Ill. The heparin was stored dessicated and refrigerated. The company assay listed the heparin to have an activity of 165 units per milligram (USP) or 171.3 units per milligram as received.

Solutions $[10 \%(\mathrm{w} / \mathrm{v})]$ of Biomer and polyvinyl chloride were prepared by stirring resins in $N, N$-dimethylacetamide (spectral grade) for 12 to $24 \mathrm{~h}$. The polymer solutions were filtered $(0.22 \mu \mathrm{m})$ to remove particulates. The filtered solutions were cast against cleaned glass plates. These cast solutions were then heated to $50^{\circ} \mathrm{C}$ in a vacuum oven, at atmospheric pressure, for $24 \mathrm{~h}$ to drive off the solvent. The films were then stripped from the plates and replaced in the heated vacuum oven $\left(50^{\circ} \mathrm{C}, 20\right.$ $\mu \mathrm{m} \mathrm{Hg}$ Torr) for $24 \mathrm{~h}$ to remove all residual solvents.

A $10 \%(\mathrm{w} / \mathrm{v})$ solution of polystyrene (PS) was made by stirring PS granules in dichloromethane (spectral grade) for 1 to $2 \mathrm{~h}$. The PS solution was then filtered $(0.22 \mu \mathrm{m})$ and cast against clean glass plates. The cast solution was placed in a laminar flow hood for $24 \mathrm{~h}$ at room temperature to allow the solvent to 
evaporate. The resultant rigid films were then removed from the plate support and placed under heated vacuum $\left(50^{\circ} \mathrm{C}, 20 \mu \mathrm{m} \mathrm{Hg}\right.$ Torr $)$ for $24 \mathrm{~h}$ to remove any residual solvent.

The substrate surfaces were cleaned following a protocol described elsewhere $(24,61,62)$. The procedure was utilized to remove surface contaminants in the micron range and larger prior to experimental use. All materials were handled with gloved hands or with metal forceps and cleaning was done in a clean room free from micron-sized particles.

Polystyrene beads, $1.00 \mathrm{~mm}$ diameter, were cleaned by the methodology of Coleman $e t$ al. (23). Polystyrene beads were placed in an extraction thimble (fat-extracted cellulose, Whatman) and refluxed in a Soxhlet extractor with petroleum ether (reagent) for $24 \mathrm{~h}$ followed by drying under heated vacuum $\left(50^{\circ} \mathrm{C}\right.$, $20 \mu \mathrm{m} \mathrm{Hg}$ Torr) for at least $24 \mathrm{~h}$.

Cleaned fused amorphous silica slides were treated for $5 \mathrm{~min}$ in oxygen plasma produced by a Plasmod (Tegal Corp., Richmond, Calif.) according to the methodology of King et al. $(24,61)$. Slides prepared in this fashion were immediately used and were never stored for longer than eight hours in glass containers that had been cleaned in a similar fashion.

In order to produce a more hydrophobic surface, previously cleaned and radiofrequency glow-discharged silica slides were vapor-silanized according to the methodology of Haller (25) using $N$-propyltriethoxysilane. This silanization procedure covalently links the silane groups to the surface of the silica slides, masking the hydrophilic silica surface. The resultant silica has $N$-propyltriethoxysilane covalently attached to the surface (NPS-silica).

Disposable polypropylene columns $(0.8$ $\times 20.5 \mathrm{~cm}$, Kontex, Vineland, N.J.) were cut to 2-cm lengths and packed with either cleaned glass beads ( 1.00 to $1.05 \mathrm{~mm}$ diameter) or cleaned polystyrene beads $(1.00 \mathrm{~mm}$ diameter). The glass bead columns were then subjected to polymer solution treatments to coat the beads with the desired polymer after a modification of the methodology of BrierRussell et al. (26), described below.
Solutions $[1 \%(\mathrm{w} / \mathrm{v})]$ of Biomer in spectral grade $N, N$-dimethylacetamide, polyvinyl chloride in $N, N$-dimethylacetamide (spectral grade), polystyrene in dichloromethane (spectral grade), and Silastic adhesive (uncured) in toluene (spectral grade) were prepared and stored in sealed glass containers in a dark environment. These stock solutions were filtered $(0.22 \mu \mathrm{m})$ just prior to use. Using cleaned glass syringes, the solutions were injected slowly upward into the packed columns. The columns were continuously tapped to prevent or dislodge trapped air pockets. When the reservoir had approximately $5 \mathrm{ml}$ of polymer solution, the solution was allowed to flow back down through the column, under gravity. The last remaining drops were then "wicked" from the bottom, via capillary action, with a clean dry cloth. Columns were stored covered at room temperature for $24 \mathrm{~h}$ to allow the solvent to evaporate. The columns were then placed under heated vacuum $\left(50^{\circ} \mathrm{C}, 20 \mu \mathrm{m} \mathrm{Hg}\right.$ Torr $)$ for $24 \mathrm{~h}$ to remove all residual solvents. This solution injection/draining procedure was repeated five times to insure complete polymeric coverage of the glass beads.

Random columns were selected for observation and characterization by scanning electron microscopy and X-ray photoelectron spectroscopy. The columns were assumed to have a packing efficiency of 0.74 (a closepacked system) and thus a void volume of approximately $0.8 \mathrm{ml}$. The volume of the columns was $1.0 \mathrm{~cm}^{3}$ and, assuming only point contact between spheres, yielded an effective surface area of $50 \mathrm{~cm}^{2}(27)$.

All substrate materials were characterized according to a modified version of the suggested Level II characterization of surfaces by the National Heart, Lung and Blood Institute (22). The materials were subjected to light microscopy, scanning electron microscopy, surface energetics characterization (Wilhelmy plate contact angle), and X-ray photoelectron spectroscopy $(28,29)$.

The commercially available sodium salt of heparin was fractionated by gel permeation chromatography. 
Samples of low-molecular-weight (LMW), high-molecular-weight (HMW), and commercial sodium heparin were then characterized by an independent laboratory. The molecular weight was determined by high-performance (pressure) liquid chromatography (HPLC) using dextrans of various molecular weight as standards, according to the methodology of Hurst et al. (30).

The free amine groups on heparin were reductively methylated using a modification of an earlier protocol (31) patterned after Jentoff and Dearborn (32). The radiolabeled heparin was then lyophilized and stored at $-10^{\circ} \mathrm{C}$ until used. Unless otherwise stated, all labeling procedures had an effective degree of labeling of approximately 0.8 labels per molecule.

Proteins of interest were iodinated using immobilized lactoperoxidase-glucose oxidase with labeled sodium iodide. From 0.25 to 1.00 $\mathrm{g}$ of protein was dissolved in $0.375 \mathrm{ml}$ PBS, $\mathrm{pH}$ 7.4. A suspension of immobilized lactoperoxidase and immobilized glucose oxidase (Enzymobeads, Bio-Rad, Richmond, Calif.) in $0.25 \mathrm{ml}$ distilled water (rehydrated $24 \mathrm{~h}$ prior to use) was added to the protein solution. Then, $1.0 \mathrm{mCi} \mathrm{Na}^{125}$ I (New England Nuclear, Boston, Mass.) was added (specific activity $17.4 \mathrm{Ci} / \mathrm{mg}$ and concentration $100 \mathrm{mCi} / \mathrm{ml}$ ) to this reaction mixture. Finally, $0.125 \mathrm{ml}$, of a freshly prepared solution of $1 \%(w / v) \beta-\mathrm{D}(+)$ glucose (Sigma) in water was added to the reaction solution. The solution was capped and allowed to stand unagitated for $30-35 \mathrm{~min}$. The reaction was stopped by passing the reactants through two previously characterized Sephadex G-25 columns. The labeled protein eluted entirely in the void volume while the Enzymobeads did not elute at all. The remaining reactants and unwanted by-products eluted in the last portion of the total volume. The protein concentration was determined by UV spectroscopy (Perkin-Elmer Lamda 7 UV-Vis spectrophotometer). All radiolabeled proteins were freshly prepared and were discarded after $24 \mathrm{~h}$. All iodinations had a degree of labeling of approximately 0.5 labels per molecule.
In order to insure that the iodination procedure did not denature the proteins, all radioiodinated proteins were characterized by ultraviolet spectroscopy, fluorescence spectroscopy and polyacrylamide gel electrophoresis. The stability of the iodinated species, with respect to the substituted iodine, was determined and any quenching effects of the iodine label on the fluorescence emission and UV absorbance was noted.

Two systems of equilibrium dialysis were utilized to detect heparin binding to proteins in solution. The first was a system wherein dialysis tubing (Spectrapor 6, Spectrum Medical Industries, molecular weight cutoff 25,000) was used to house both the protein and heparin, and the second was a system where the same dialysis tubing was cut into sheet form and clamped between two identical chambers. The advantage of the second method, when compared to the first, is that it was easier to insure that leakage into the buffer reservoir did not occur. The first system utilized a 2-ml reservoir and a 6-ml buffer surround. The second system consisted of two identical chambers of $5 \mathrm{ml}$ volume each separated by dialysis sheeting.

The systems were characterized (33) in separate control experiments by placing tritiumlabeled heparins (LMW, HMW, and commercial sodium heparin) with phosphatebuffered saline (PBS), $\mathrm{pH} 7.4\left(2 \mathrm{mM} \mathrm{KH}_{2} \mathrm{PO}_{4}\right.$, $8 \mathrm{~m} M \mathrm{Na}_{2} \mathrm{HPO}_{4}$, and $\left.145 \mathrm{mM} \mathrm{NaCl}\right)$, in the reservoirs and allowing them to diffuse until equilibrium was reached.

Protein binding to heparin was determined for all three heparins by adding the proteins and ${ }^{3} \mathrm{H}$-heparin in the same reservoir (33) so that the final concentration of protein was 1.5 $\times 10^{-6} \mathrm{M}$. The final ${ }^{3} \mathrm{H}$-heparin concentration was 50,25 , and $10 \mu \mathrm{g} / \mathrm{ml}$, in separate experiments. The buffer was mildly stirred (system 1) or the entire system was rotated gently (system 2) on a laboratory rotator for $24 \mathrm{~h}$, at which time the samples were taken. The extent of binding and binding kinetics were determined by comparing the amount of ${ }^{3} \mathrm{H}$-heparin on the reservoir side versus the unbound 
TABLE I

Contact Angle Results Using Wilhelmy

Plate (Mean \pm SD)

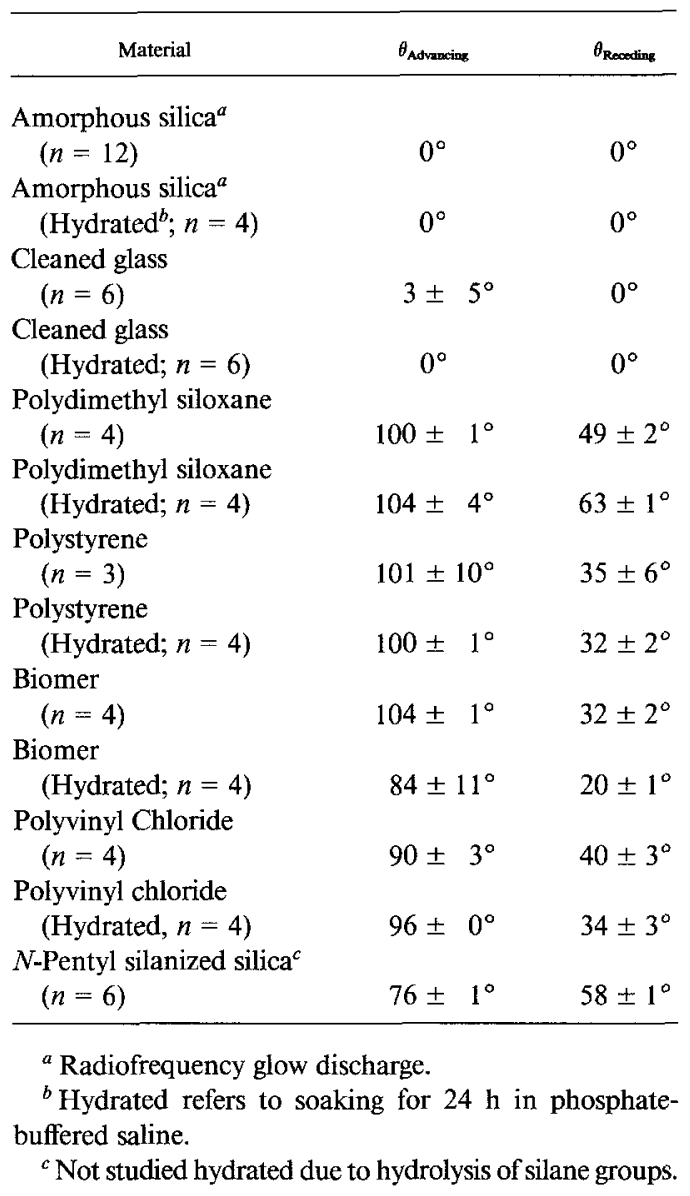

${ }^{3} \mathrm{H}$-heparin concentration diffused to the buffer side. The amount of bound ${ }^{3} \mathrm{H}$-heparin to protein $\left(C_{\mathrm{B}}^{\mathrm{Hep}}\right)$ is determined by

$$
C_{\mathrm{B}}^{\mathrm{Hep}}=C_{\mathrm{Res}}^{\mathrm{Hep}}-C_{\mathrm{Buffer}}^{\mathrm{Hep}}
$$

where

$$
\begin{aligned}
C_{\mathrm{Res}}^{\mathrm{Hep}}= & \text { Concentration of }{ }^{3} \mathrm{H}-\text { heparin re- } \\
& \text { maining in the reservoir } \\
= & \text { Concentration bound }{ }^{3} \mathrm{H} \text {-heparin } \\
& + \text { Concentration free }{ }^{3} \mathrm{H} \text {-heparin in } \\
& \text { solution } \\
C_{\mathrm{Buffer}}^{\mathrm{Hep}}= & \begin{array}{l}
\text { Concentration of unbound }{ }^{3} \mathrm{H}-\text { hep- } \\
\text { arin diffused to the buffer side }
\end{array} \\
= & \text { Free heparin concentration }
\end{aligned}
$$

${ }^{3} \mathrm{H}$-Heparin concentrations were determined by liquid scintillation counting. The binding constants of ${ }^{3} \mathrm{H}$-heparin to protein were determined by Scatchard plots (35) which also yielded the number of binding sites $(n)$ according to

$$
\frac{\bar{\nu}}{[\mathrm{A}]}=n K-K \bar{\nu}
$$

where

$\bar{\nu}=$ moles bound ligand (heparin)/moles total protein

$K=$ binding (association) constant

[A] = ligand (heparin) concentration

$n=$ number of identical, noninteracting sites.

Therefore, plotting $\bar{\nu} /[\mathrm{A}]$ versus $\bar{\nu}$ yields a slope of $-K$ and an intercept of $n k$ on the $\bar{\nu} /[\mathrm{A}]$ axis or $n$ on the $\bar{v}$ axis.

Protein adsorption onto cleaned Biomer, polyvinyl chloride, polydimethylsiloxane (Silastic), amorphous silica, and polystyrene substrate disks was done in an adsorption cell. The cells themselves were 1-ml disposable cuvettes capped with clean 00 corks. Tygon tubing was introduced into bored holes in the corks and stoppered on the outer ends with three-way stopcocks.

Substrates were introduced into the cells with clean forceps and the cells then corked. The closed cells were then primed with degassed PBS (pH 7.4) until all air was removed. The cells were allowed to sit at room temperature for at least $1 \mathrm{~h}$ prior to the introduction of labeled protein solution. Radiolabeled protein solutions were then introduced by injec-

\section{TABLE II}

Molecular Weight Determination of Heparins (Mean \pm SD)

Low molecular weight 7,600

Medium molecular weight

$$
(n=4)
$$

High molecular weight

$$
(n=4)
$$

Commercial heparin

$$
(n=4)
$$$$
27,700 \pm 8,600
$$

$20,800 \pm 10,200$ 


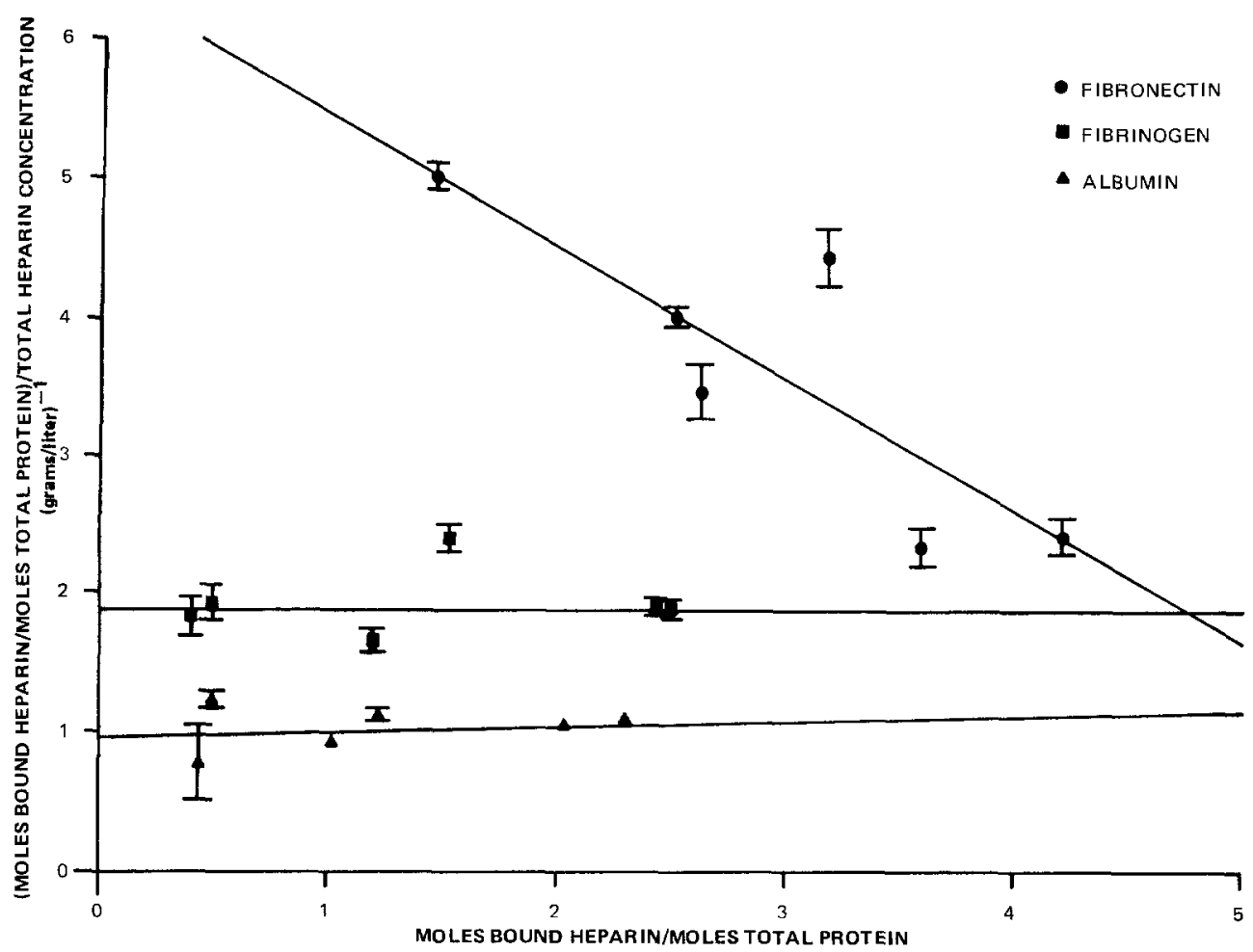

FIG. 1. Scatchard analysis of the solution binding of labeled heparins to proteins in solution. The values given are for commercial heparins but those for low-molecular-weight and high-molecular-weight heparins were not significantly different. Values are mean $\pm \mathrm{SD}(n=6)$, fibronectin, slope $=-1.02$, intercept $=6.63$, $r=0.82$; albumin: slope $=0.59, r=0.90$; fibrinogen: slope $=0.036, r=0.92$.

tion from clean disposable syringes. Ten milliliters of protein solution was injected into the cell at the rate of $40 \mathrm{ml} / \mathrm{min}$ to remove all priming buffer and to introduce the protein solution in desired concentrations. Care was taken so as not to introduce any air into the system. The cells were then allowed to remain stationary, at room temperature, for up to 24 h. To terminate protein adsorption each cell was flushed with $30 \mathrm{ml}$ PBS buffer at $60 \mathrm{ml}$ / $\mathrm{min}$, to insure that the substrates were not removed through a protein-solution/air interface. Previous studies with priming solution of Blue Dextran 2000 (Pharmacia Fine Chemicals), using light spectroscopy $(639 \mathrm{~nm})$, indicated that the dextran was removed after a 5- to 6-ml flush, at $40 \mathrm{ml} / \mathrm{min}$. Substrates were then removed and placed in dry scintillation vials. Adsorbed protein concentrations were determined by gamma counting on a gamma radiation detector.

Desorption of the protein from the substrates was determined by allowing preadsorbed protein films to desorb in fresh PBS buffer, for up to $24 \mathrm{~h}$, in new vials. The cells were then flushed to remove all desorbed protein. Remaining protein concentrations were determined by $\gamma$ radiation counting. Verification of the concentration of initially adsorbed protein layer required that the desorbed protein solution, flushed at the termination of the experiment, be counted in similar fashion.

Desorption of adsorbed radioiodinated proteins was also done in freshly prepared bovine platelet-poor plasma (PPP). Fresh whole slaughterhouse blood was collected and mixed in a $9: 1(\mathrm{v} / \mathrm{v})$ ratio with a $3.8 \%(\mathrm{w} / \mathrm{v})$ solution of sodium citrate (reagent grade) in water. PPP 
TABLE III

Values for ${ }^{3} \mathrm{H}$-Heparin Binding to Proteins ${ }^{a}$

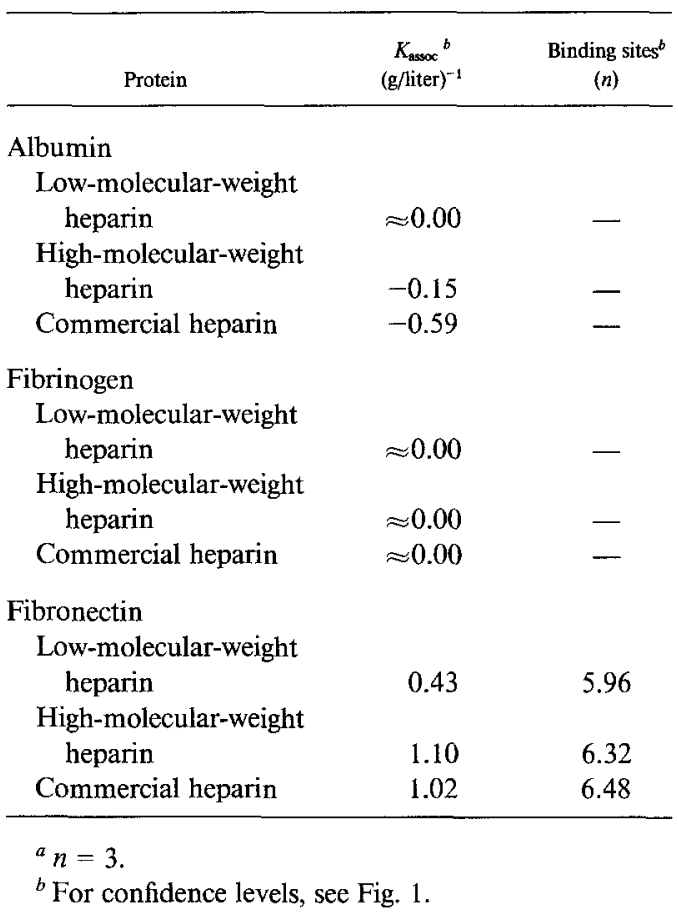

was prepared by centrifugation of the whole blood for $20 \mathrm{~min}$ at $1300 \mathrm{~g}$ force. PPP was then pipetted off and used immediately. The desorption experiments with PPP was the same as above, except that PPP was used as the desorption medium. Flushing was still done with PBS buffer. Maximum desorption time was 8 h with PPP.

Native proteins were adsorbed onto clean Biomer, PVC, PS, PDMSO, and glass substrate disks (planchettes) from $0.3 \mathrm{mg} / \mathrm{ml}$ protein solution left for $24 \mathrm{~h}$. After buffer flushing, 10 $\mathrm{ml}$ of $0.1 \mathrm{mg} / \mathrm{ml}$ solution of either LMW, $\mathrm{HMW}$, or commercial ${ }^{14} \mathrm{C}$-heparin, in PBS, was injected into the cell. The ${ }^{14} \mathrm{C}$-heparin was allowed to interact with the adsorbed protein layer for $1 \mathrm{~h}$ whereupon the cells were flushed with $30 \mathrm{ml}$ PBS buffer at $60 \mathrm{ml} / \mathrm{min}$ to remove all desorbed protein and unbound heparin. The substrates were then air-dried at room temperature and the amount of bound ${ }^{14} \mathrm{C}$-heparin determined by counting on a "planchet type" gas ionization radiation detector (Internal Proportional Counter, Eberline 2200) for $5 \mathrm{~min}$ (high voltage at $96.75 \mathrm{~V}$, window at $96 \mathrm{~V}$, and threshold at $40 \mathrm{~V}$ ).

Quantitation was done by subtraction of CPM of ${ }^{14} \mathrm{C}$-heparins on controls (no adsorbed protein) from CPM of ${ }^{14} \mathrm{C}$-heparins bound to adsorbed protein substrates. This modified CPM was further corrected by dividing by the efficiency, found from a calibrated $\gamma$-source, yielding effective degradations per minute (DPM). This DPM value was then divided by the specific activity to yield the amount of ${ }^{14} \mathrm{C}$-heparin bound.

Previously prepared columns of polystyrene beads, glass beads, and polymer-coated glass beads of Biomer, polyvinyl chloride, and polydimethylsiloxane were primed, from the bottom, with PBS for $1 \mathrm{~h}$. Excess buffer was then pipetted off and $10 \mathrm{ml}$ of native protein solution $(0.3 \mathrm{mg} / \mathrm{ml})$ was introduced the same way as was the buffer. Proteins were allowed to adsorb for $24 \mathrm{~h}$. After having excess protein solution pipetted from the column reservoir, the columns were then flushed with $30 \mathrm{ml}$ PBS buffer. Solutions $(0.1 \mathrm{mg} / \mathrm{ml})$ of ${ }^{14} \mathrm{C}$-labeled heparin of commercial molecular weight, were then introduced, as above, in $10-\mathrm{ml}$ aliquots and allowed to interact for up to $8 \mathrm{~h}$.

Kinetics of ${ }^{14} \mathrm{C}$-heparin binding were monitored by solution depletion techniques. The stock ${ }^{14} \mathrm{C}$-heparin solution activity was compared to the activity of $100-\mu 1$ samples drawn from the bottom of the column. Activity and quantitation were accomplished by liquid scintillation counting.

Release (desorption) of ${ }^{14} \mathrm{C}$-heparin was done in both PBS buffer and bovine platelet poor plasma (PPP). At binding equilibrium, the ${ }^{14} \mathrm{C}$-heparin solution was pipetted from the reservoir and the column flushed with $30 \mathrm{ml}$ PBS buffer. Again, excess buffer was removed from the reservoir. At this time PBS buffer release of ${ }^{14} \mathrm{C}$-heparin was initiated. Samples were taken by injecting $1 \mathrm{ml}$ PBS buffer from below and removing the same volume of buffer from the reservoir. Desorption was allowed for up to $24 \mathrm{~h}$. 
(a)

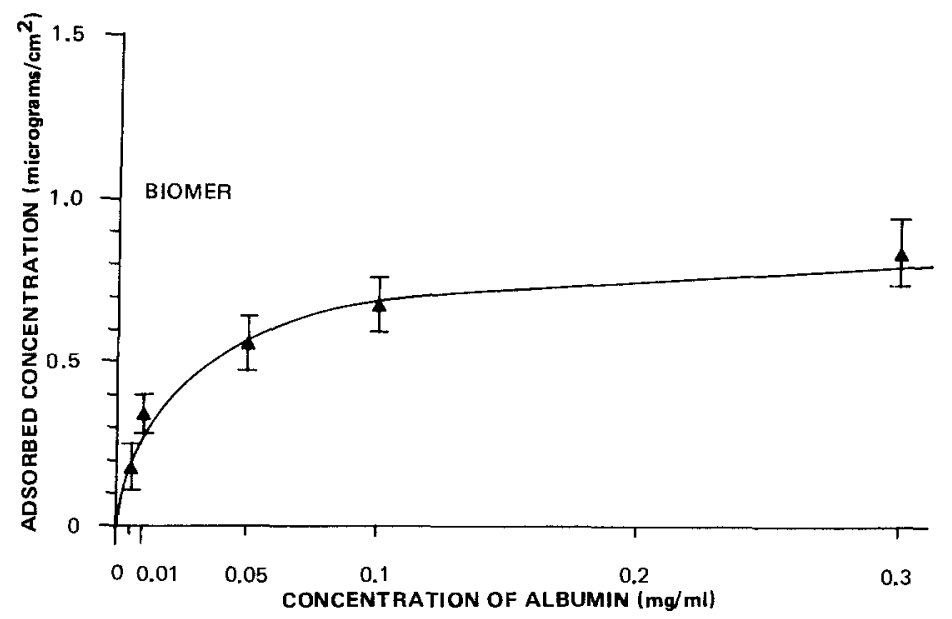

(b)

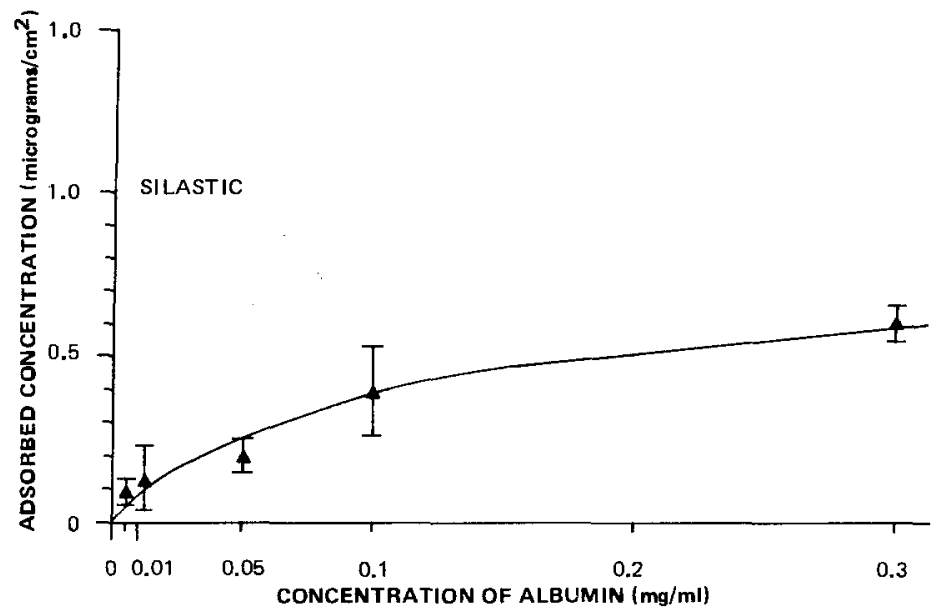

(c)

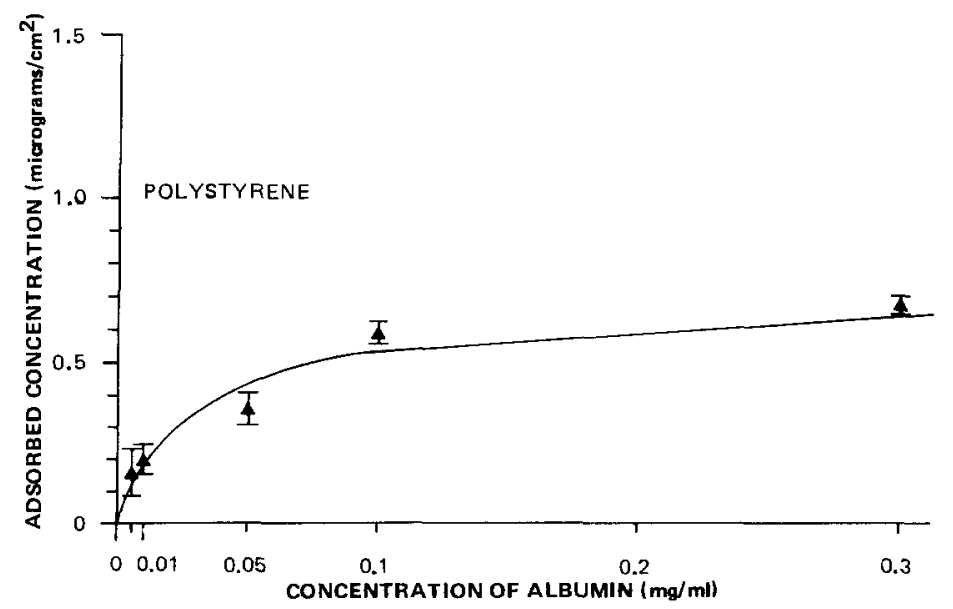

FIG. 2. ${ }^{125}$ I-Albumin static adsorption isotherms on disks taken at room temperature. Values given are mean $\pm \mathrm{SD}(n=3)$ for all points except $0.3 \mathrm{mg} / \mathrm{ml}$, where $n=9$. (a) Biomer, (b) Silastic, (c) polystyrene, (d) polyvinyl chloride. 
(d)

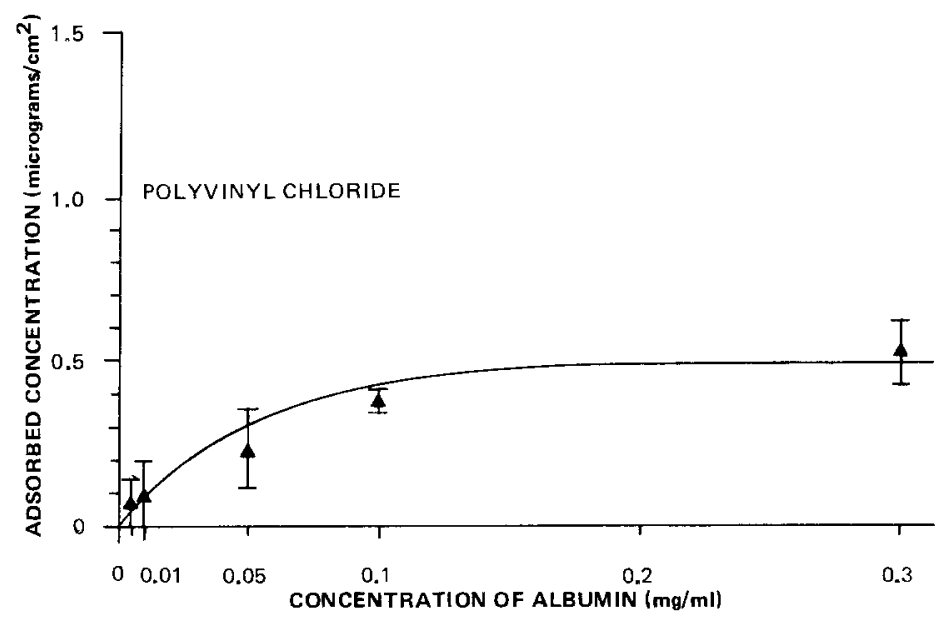

FIG. 2-Continued.

Release of ${ }^{14} \mathrm{C}$-heparin in bovine PPP was done as above except that PPP was introduced by a second flush of $20 \mathrm{ml}$ plasma to remove excess PBS buffer. Samples were taken in a similar manner. Plasma release studies were done for up to $8 \mathrm{~h}$.

All plasma and buffer samples were counted by liquid scintillation counting.

The total amount of ${ }^{14} \mathrm{C}$-heparin released could be due to: (a) released ${ }^{14} \mathrm{C}$-heparin from nondesorbing protein, $C_{\mathrm{R}}$; and (b) "released" heparin still bound to desorbed protein, $C_{\mathrm{B}}$. If $C_{\mathrm{B}}$ is equal to the amount of desorbed protein $\left(C_{\mathrm{p}}\right)$ (previously determined) then the true amount of ${ }^{14} \mathrm{C}$-heparin actually released from protein, $C$, is given by

where

$$
C=C_{\mathrm{H}}-C_{\mathrm{p}}
$$

$$
\begin{aligned}
C_{\mathrm{H}}= & C_{\mathrm{R}}+C_{\mathrm{B}} \\
= & \text { Amount determined by liquid scintil- } \\
& \text { lation counting. }
\end{aligned}
$$

Fresh human whole blood was obtained from healthy donors and immediately mixed in a $9: 1(\mathrm{v} / \mathrm{v})$ ratio with a $3.8 \%(\mathrm{w} / \mathrm{v})$ solution of sodium citrate (Reagent grade). Platelet poor plasma (PPP) was obtained by centrifugation of the whole blood for $10 \mathrm{~min}$ at $2200 \mathrm{~g}$ force. The PPP was decanted off and used im- mediately or stored frozen for up to 2 weeks. Human PPP was introduced into buffer primed Biomer columns according to the methodology previously discussed. PPP was allowed to remain in the columns for $1 \mathrm{~h}$ to allow for plasma protein adsorption, then the columns were flushed with $30 \mathrm{ml}$ PBS $(\mathrm{pH}$ 7.4) at approximately $60 \mathrm{ml} / \mathrm{min}$. Solutions of commercial ${ }^{14} \mathrm{C}$-heparin $(0.1 \mathrm{mg} / \mathrm{ml})$ were introduced and the kinetics of binding monitored for up to $24 \mathrm{~h}$ via solution depletion. Release of ${ }^{14} \mathrm{C}$-heparin was done as previously described in both PBS buffer and human PPP.

Activated partial thromboplastin time (APTT) and anti- $\mathrm{X}_{\mathrm{a}}$ assays (34) were performed to determine the activity/presence of the bound and/or released heparins from substrates coated with plasma fibronectin and pooled human PPP.

\section{RESULTS AND DISCUSSION}

The substrate surfaces characterized were clean. There were no observed particulates or chemical impurities in the matrix. Most of the surfaces were macroscopically smooth. However, some roughness was observed on Biomer, Silastic, polystyrene beads, and glass bead surfaces at high magnification (36). All surfaces were wettable to different extents (see Table I) 
(a)

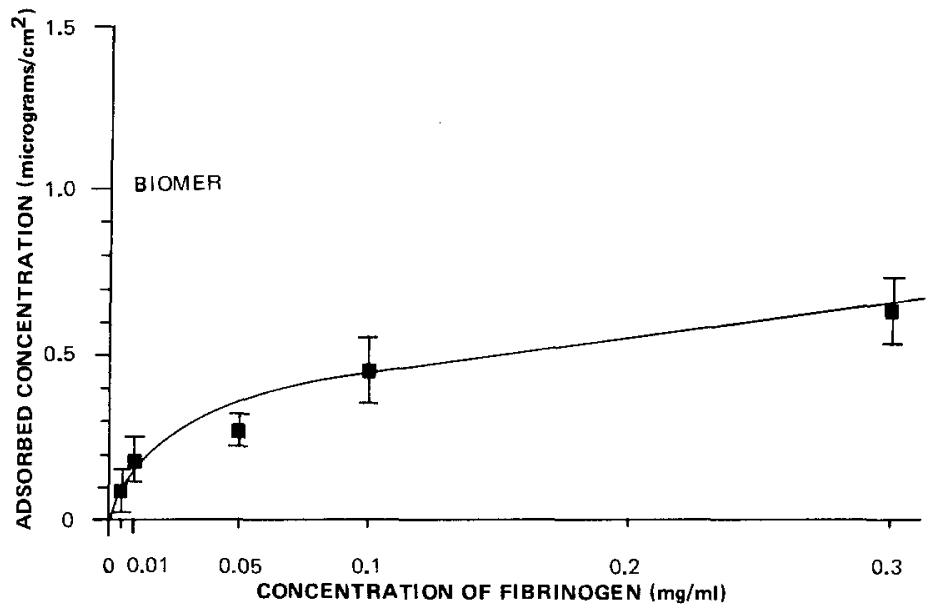

(b)

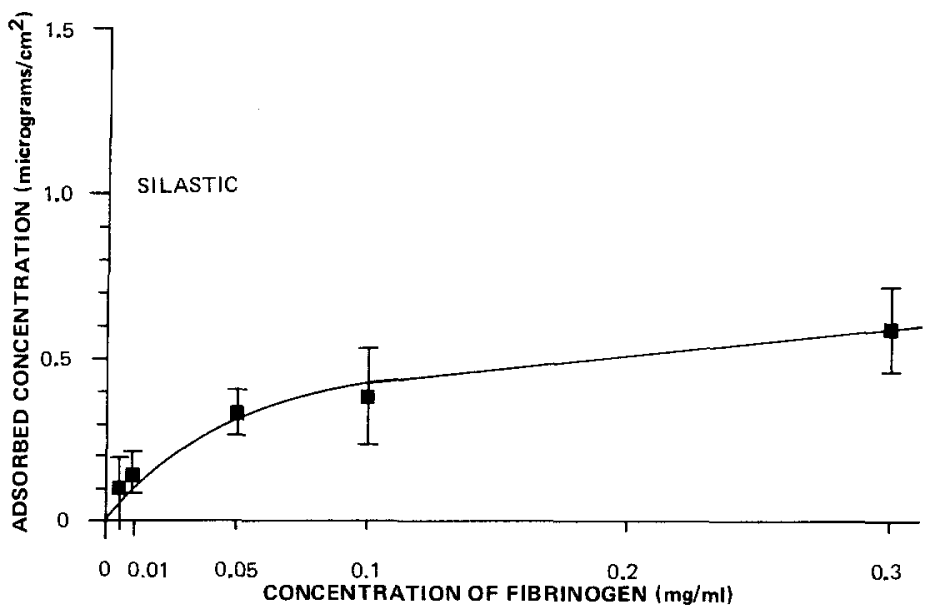

(c)

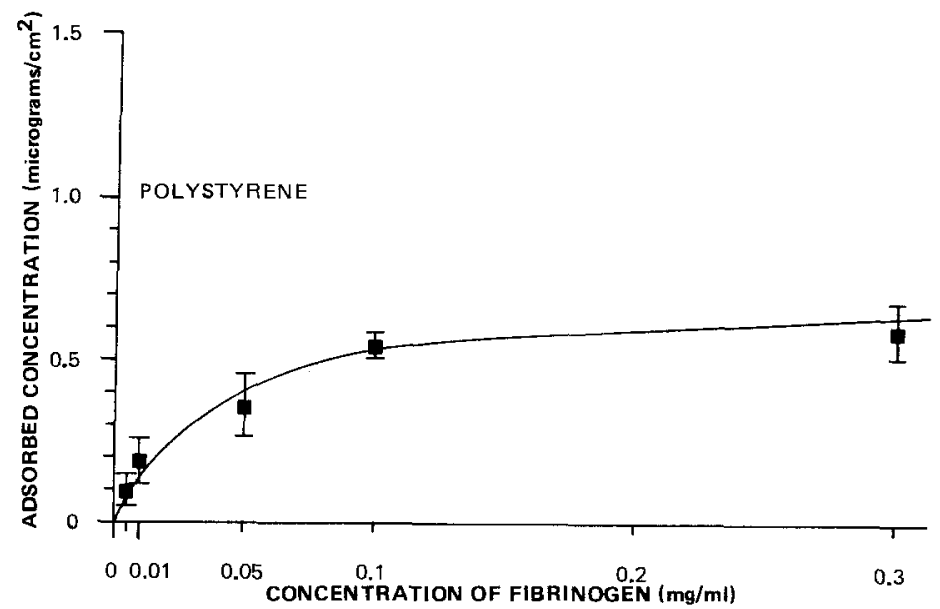

FIG. 3. ${ }^{125}$ I-Fibrinogen static adsorption isotherms on disks taken at room temperature. Values are mean $\pm \mathrm{SD}(n=3)$ for all points except for $0.3 \mathrm{mg} / \mathrm{ml}(n=9)$. (a) Biomer, (b) Silastic, (c) PS, (d) PVC. 
(d)

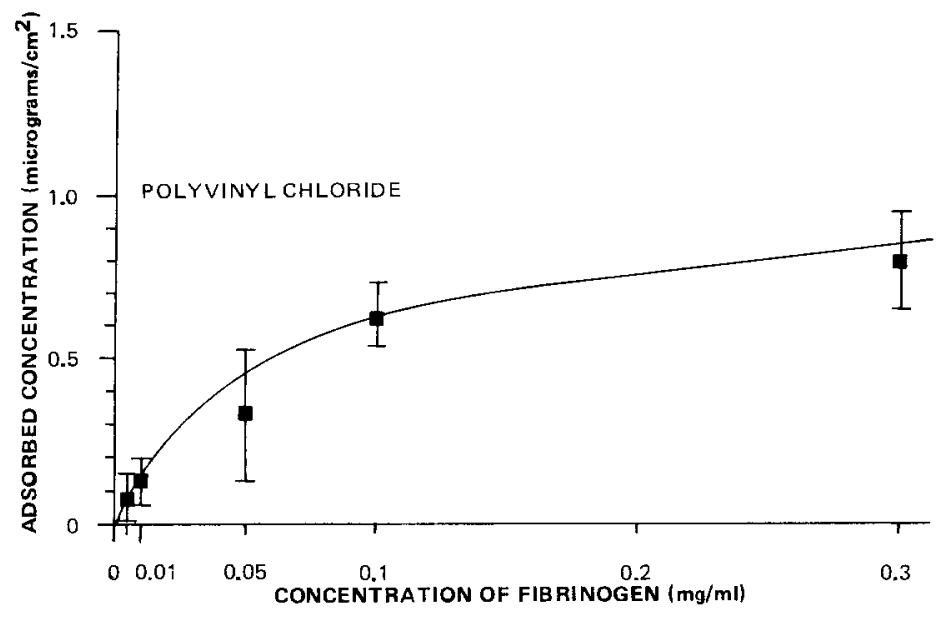

Fig. 3-Continued.

as indicated by the receding angle observed via Wilhelmy plate energetics. The substrate surfaces were clean and chemically accounted for by XPS examination. The solution technique of coating the glass bead supports was shown to be complete by scanning electron microscopy and XPS analyses (36).

Utilizing high-pressure liquid chromatography, the fractionated heparins were characterized by reference to known dextran molecular weights. This methodology yields the molecular weight relative to dextrans; therefore, the absolute molecular weights are still unknown. Another disadvantage to this methodology is that the molecular weight distribution (i.e., weight average molecular weight, number average molecular weight) remains unresolved. However, the relative values were consistent and thus considered reliable. Since heparins are chain-like structures and not globular in nature, like dextrans, it was necessary to multiply the values obtained by an empirically derived factor (30) to compensate and yield more "accurate" relative molecular weights. The results are listed in Table II for LMW fractions, medium-molecular-weight fractions (not utilized), and HMW fractions. The average molecular weight for commercial heparin was determined from the values listed.
The optical properties of the labeled proteins, studied here, which are indicative of conformation, seem to be identical to the native proteins (36). Also, the electrophoretic mobility was unchanged, which indicates similar conformation and that no fragmentation occurred during iodination (64). Even so, it still cannot be concluded that the iodinated protein is equivalent to the native structure. Indeed, iodide has a relatively large atomic radius and is extremely large when compared to the hydrogen atomic size that it has been substituted for. In this study the iodination performed was done under conditions much milder than the manufacturers' recommendations for iodination and the resultant specific labeling was much lower than those reported by the manufacturers. Since there was only up to one label per protein considered (usually only 0.5 ), it is highly unlikely that the same tyrosine is labeled every time in the respective proteins considered. This being the case, perhaps the localized iodine effects are either masked by the large surrounding host or so small that accommodation by the relatively immense protein is accomplished without any macroscopically observable effects. In either case, one may be certain that the electronegativity and size of the iodide substitution has a massive localized effect. It is assumed 
(a)

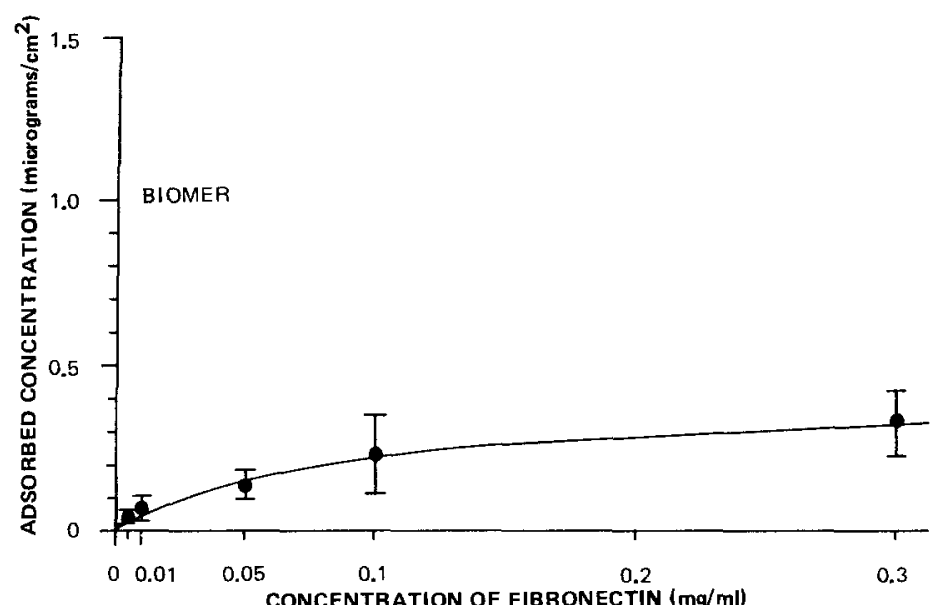

(b)

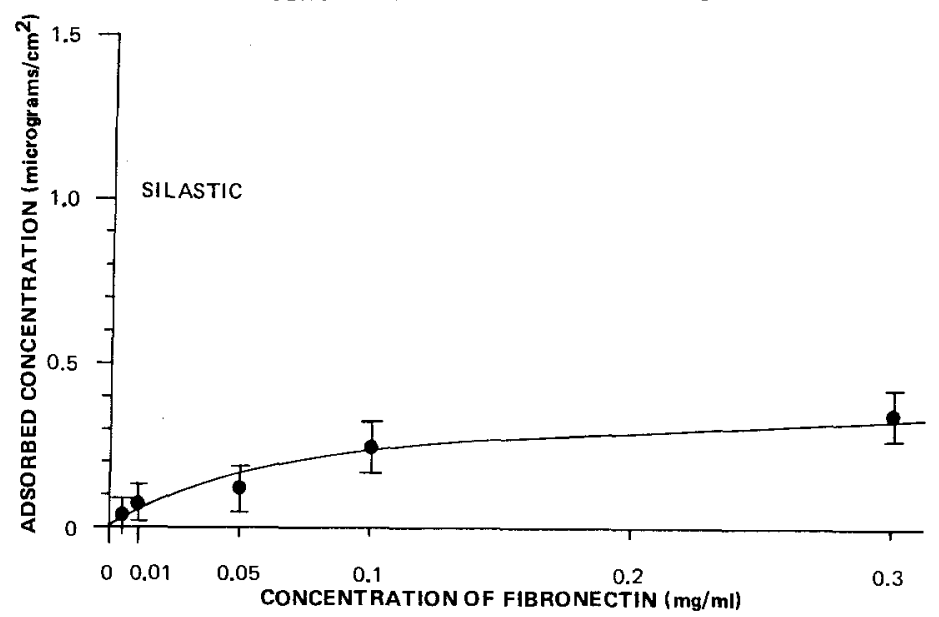

(c)

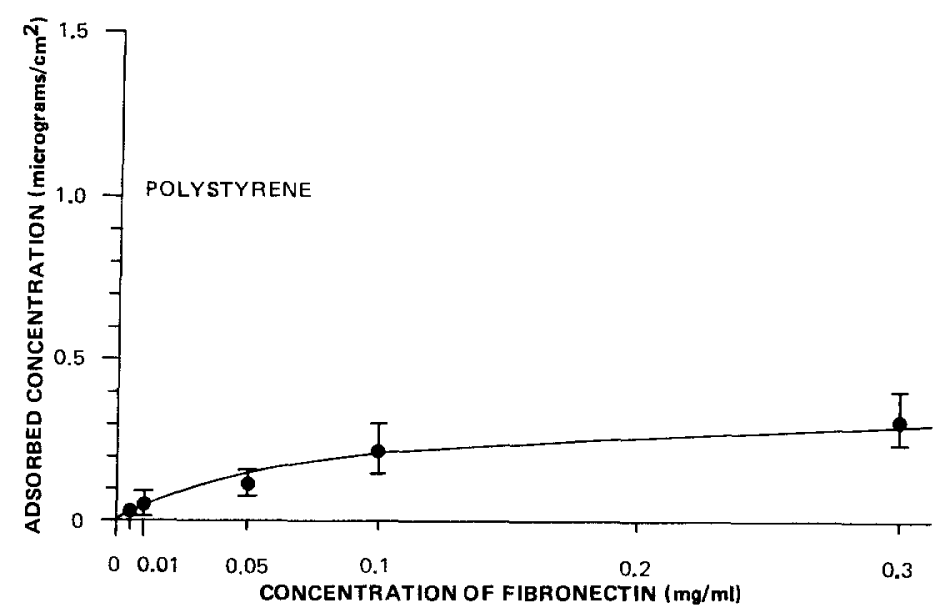

FIG. 4. ${ }^{125}$ I-Fibronectin static adsorption isotherms on disks taken at room temperature. Values given are mean $\pm \mathrm{SD}(n=3)$ for all points except $0.3 \mathrm{mg} / \mathrm{ml}$ where $n=9$. (a) Biomer, (b) Silastic, (c) PS, (d) PVC, (e) hydrophilic silica. 
(d)
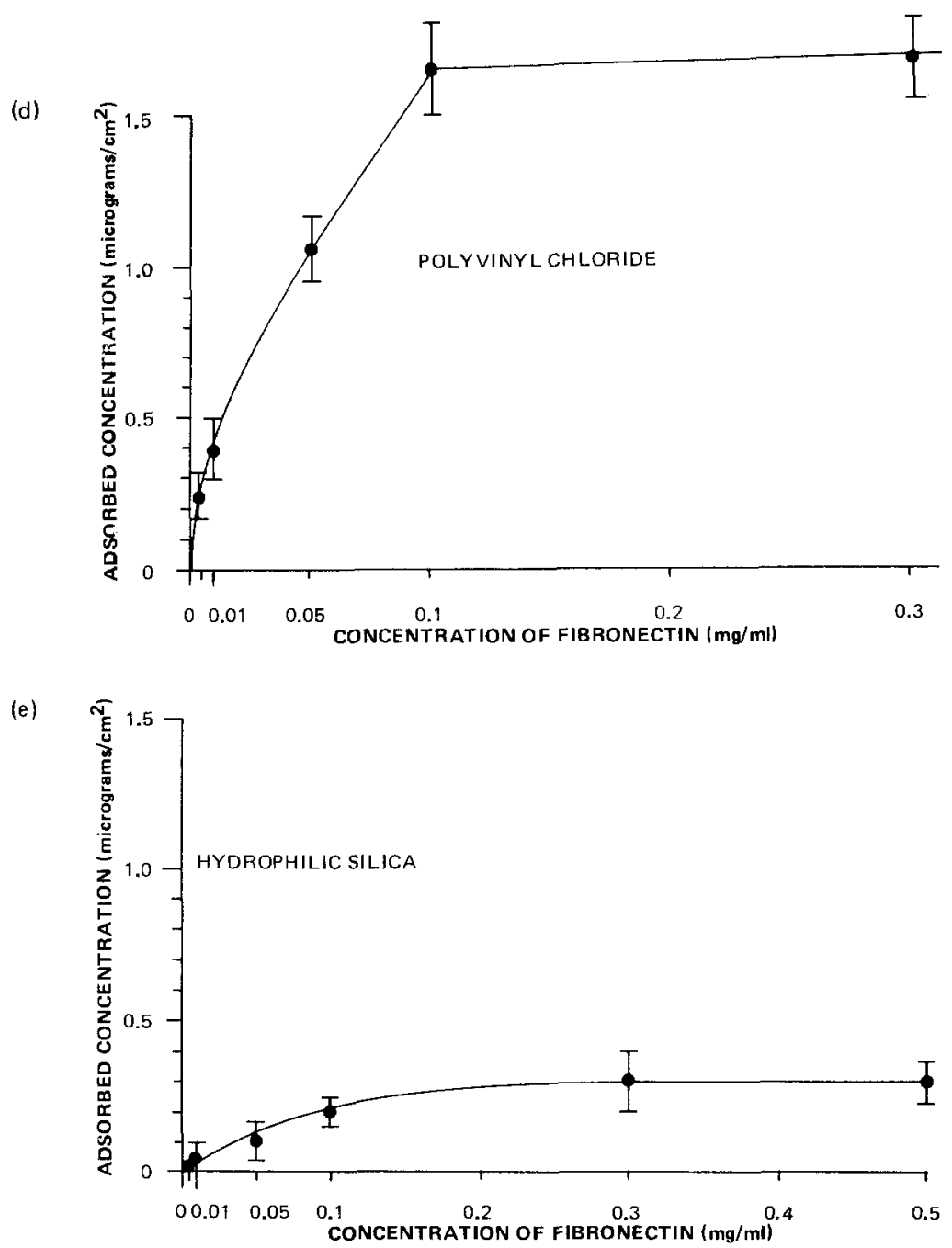

FIG. 4-Continued.

that this localized effect can be negated for our purposes since no preferential adsorption/rejection of iodinated proteins was observed in this study.

The binding of tritiated heparin fractions to albumin, fibrinogen and fibronectin was examined via equilibrium dialysis. The results are given in Fig. 1. The resultant values for HMW and $\mathrm{LMW}{ }^{3} \mathrm{H}$-heparin fractions were not significantly different from commercial heparin, in any instance. The association (binding) constant ( $\left.K_{\text {assoc }}\right)$ for albumin-
${ }^{3} \mathrm{H}$-heparin is from approximately 0 to -0.5 $(\mathrm{g} / \text { liter })^{-1}$ indicating a mutual nonaffinity of ${ }^{3} \mathrm{H}$-heparin and albumin. Fibrinogen shows similar results with $K_{\text {assoc }}$ being equal to zeroa noninteraction or nonassociation between ${ }^{3} \mathrm{H}$-heparin and fibrinogen. Figure 1 further shows the rather strong affinity of ${ }^{3} \mathrm{H}$-heparin for plasma fibronectin. $K_{\text {assoc }}$ is nearly equal to unity and the number of binding sites $(n)$ is equal to 6 . The negative slope on a straight line (fit by linear regression, $R=0.82$ ) is indicative of noncooperative binding of six in- 
(a)

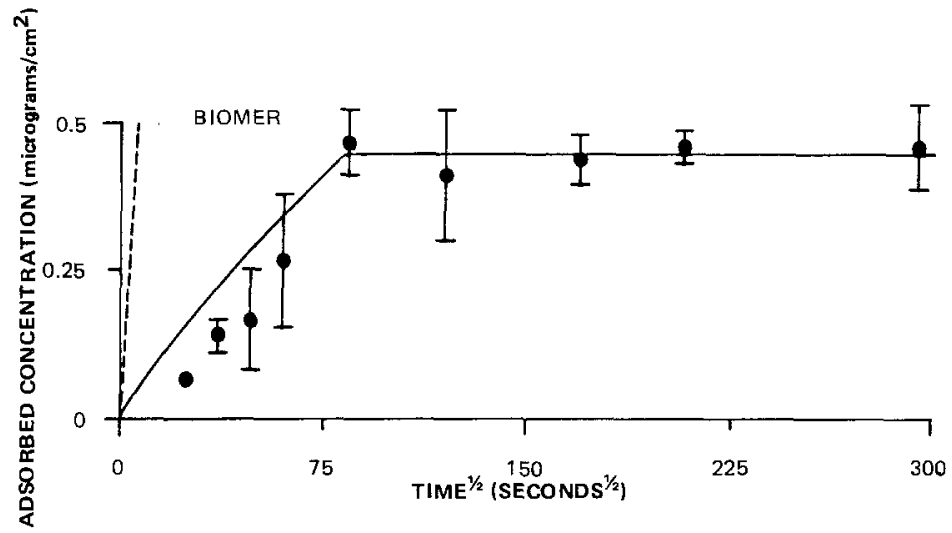

(b)
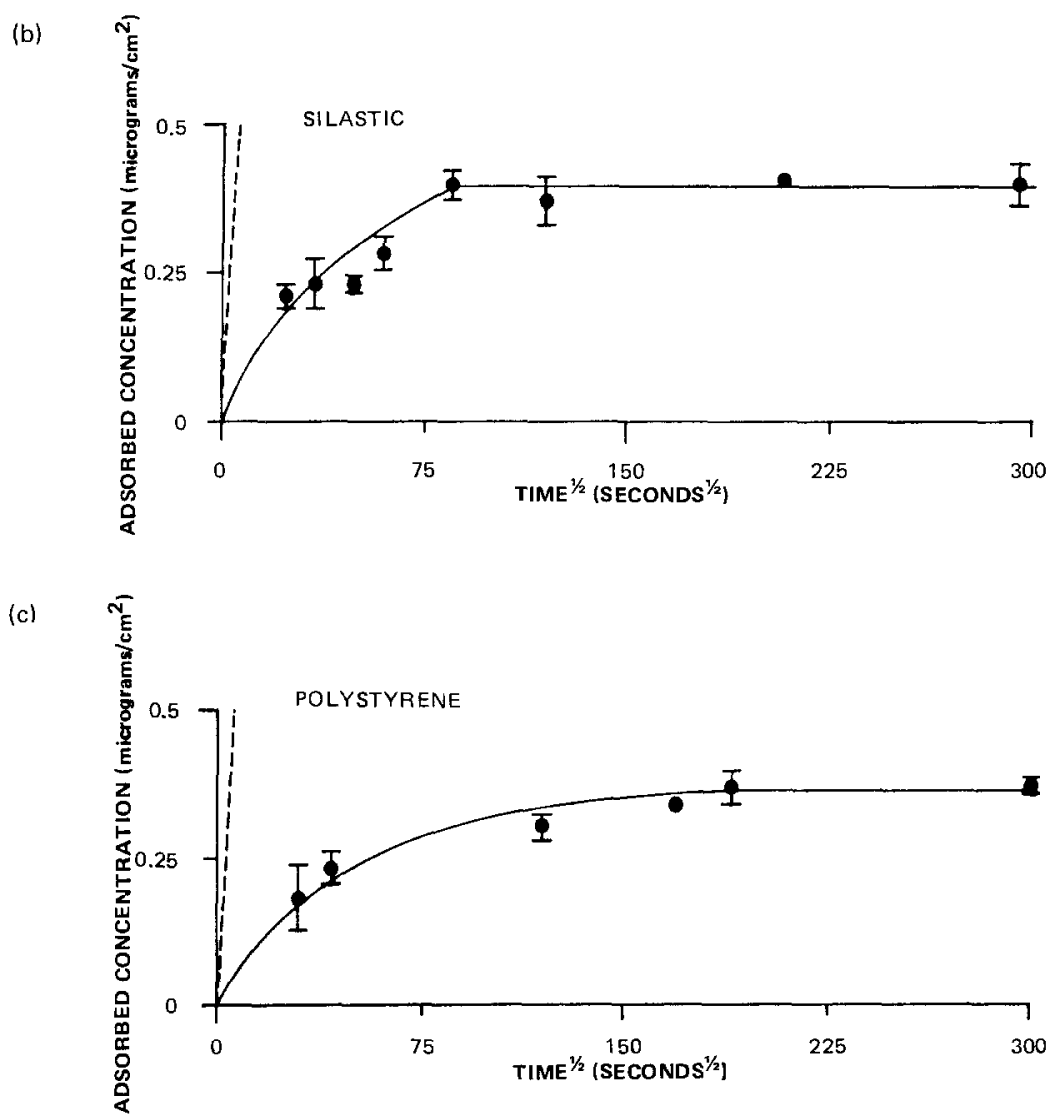

FIG. 5. Kinetics of ${ }^{125}$ I-fibronectin static adsorption on disks. Concentration $=0.05 \mathrm{mg} / \mathrm{ml}$. Dashed line is the theoretically calculated diffusion control process. Values are mean $\pm \mathrm{SD}(n=3)$ (last point $n=6)$.

(a) Biomer, (b) Silastic, (c) PS, (d) PVC, (e) hydrophilic silica.

dependent sites. Fibronectin has been shown (37-41) to have three binding sites for heparin on each of its two segments. Thus, the binding of six heparins per fibronectin molecule, in solution, indicates that in the "native" solution state that all six sites are active in binding. 
(d)

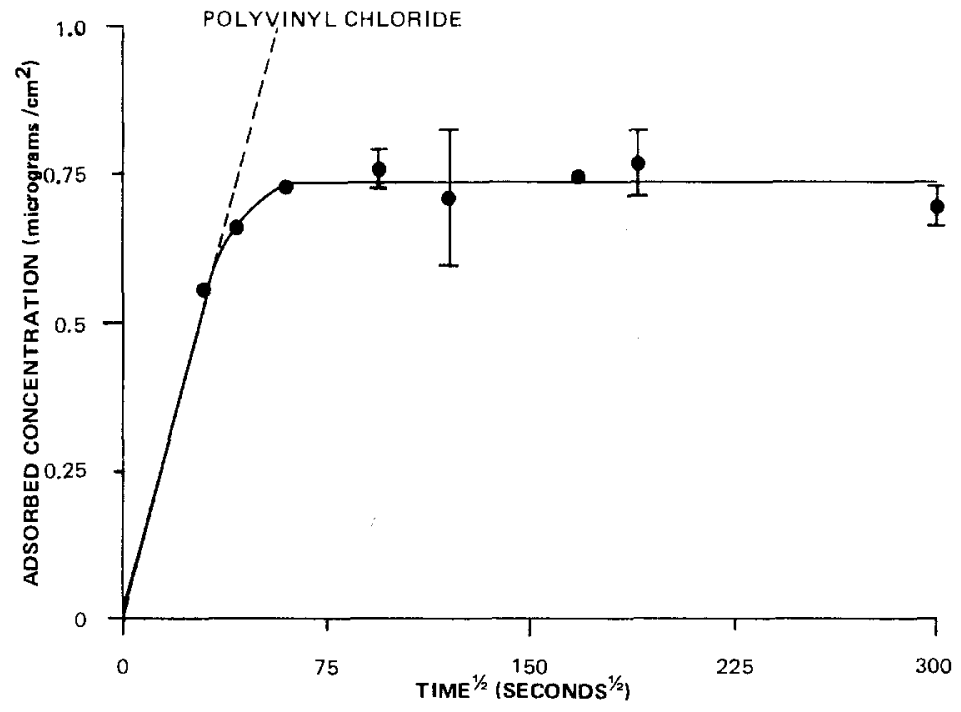

(e)

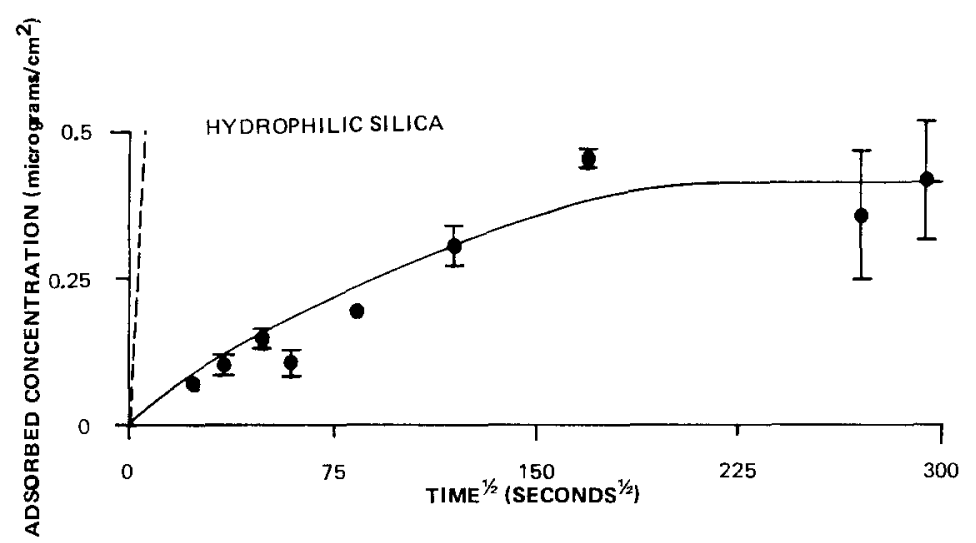

FIG. 5-Continued.

While it is customary to report $K_{\text {assoc }}$ in terms of moles per liter $(M)$, due to the polydispersity of heparin and the heparin fractions used herein, it was felt that reporting $K_{\text {assoc }}$ in terms of grams per liter is much more descriptive (see Table III).

In this study, each adsorption was run at least three times using ratios of labeled to unlabeled protein of approximately 1:4, 1:2, and $1: 1$ to determine the effect of protein labeling on adsorption. Each of the labeled protein fractions had approximately equal degrees of labeling (approximately 0.5 ). No increase in adsorption was observed with increased la- beled-protein concentration. All adsorption values were within the error limits of gamma counting efficiency. The preferential and nonpreferential adsorption of the same labeled species has been shown to be substrate (system) dependent $(7,42)$. For example, in this study, iodinated (iodine-125) albumin was shown to nonpreferentially adsorb to polystyrene while others have shown preferential adsorption onto polystyrene latices (43). Those latices were well oriented with respect to charge and backbone, while the polystyrene utilized herein was random in nature. Conjugated albumin has also shown no preferential adsorp- 
(a)

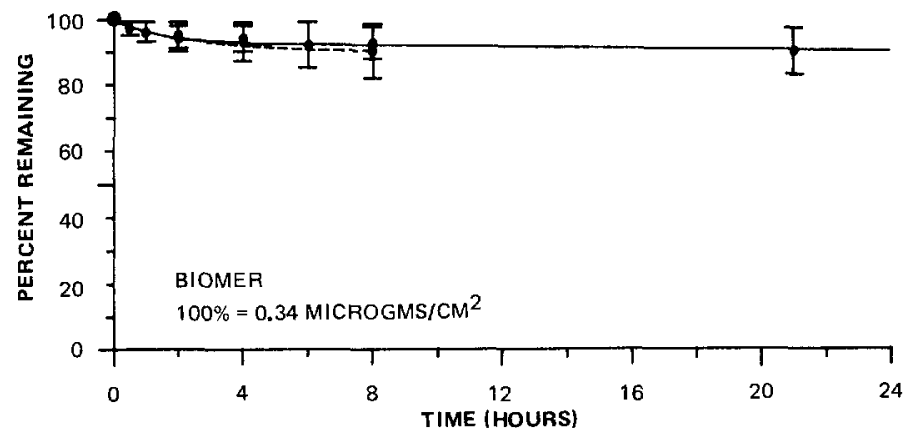

b)

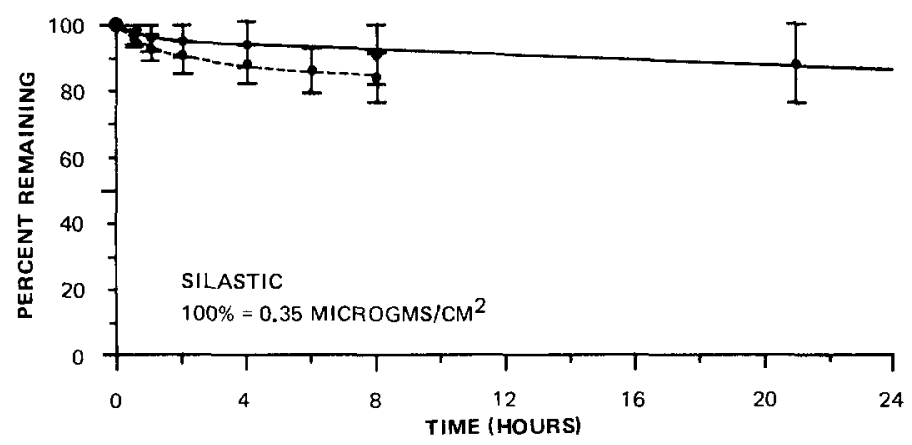

(c)

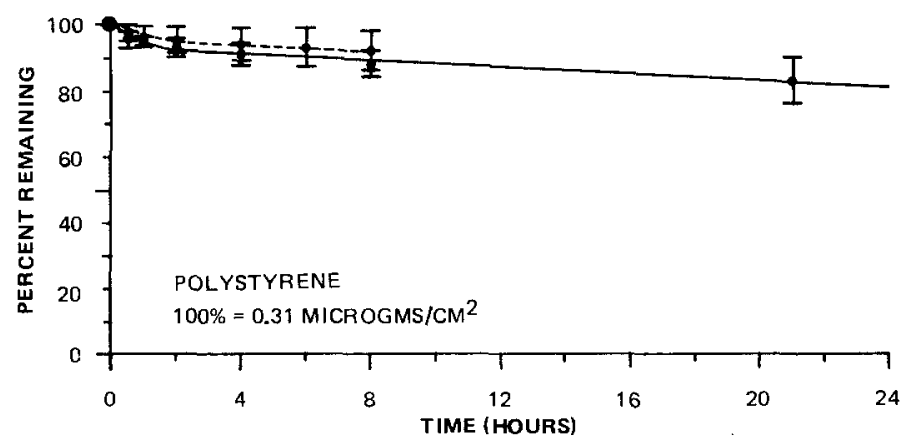

FIG. 6. Static desorption of ${ }^{125}$ I-fibronectin on disks. Dashed line is in plasma medium and solid line is in PBS buffer. Values given are mean \pm SD $(n=3$ ). (a) Biomer, (b) Silastic, (c) PS, (d) PVC, (e) hydrophilic silica.

tion onto amorphous silica, Biomer, Silastic, and cellulose acetate (7). Similarly, concerning labeled fibrinogen, this study showed no preferential adsorption while others (7) have shown preferential adsorption elsewhere. It should be noted, however, that these substrate surfaces here are different than those previously reported.
Figure 2 shows the adsorption isotherms of ${ }^{125}$ I-labeled albumin on the polymeric substrates utilized. The adsorbed amount, for a $0.3 \mathrm{mg} / \mathrm{ml}$ solution of iodinated albumin, falls very near to the reported values of others (4450) and nearly equal to the approximate 0.7 $\mu \mathrm{g} / \mathrm{cm}^{2}$ monolayer concentration reported on polystyrene and polyurethane substrates (45, 
(d)

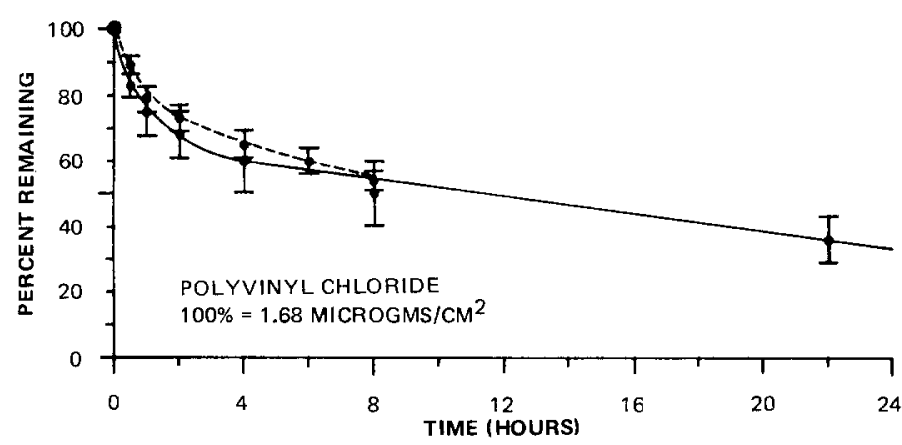

(e)

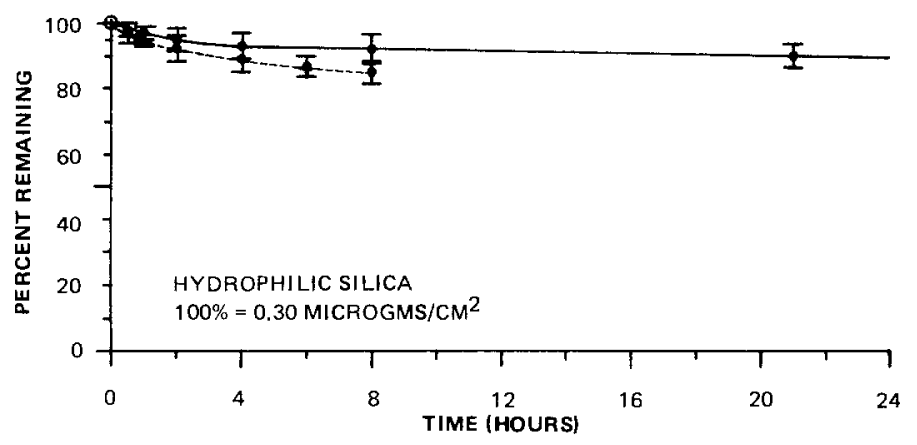

FIG. 6-Continued.

46). Assuming that the iodinated albumin undergoes no multilayering, significant structural changes upon adsorption, and that surface irregularities can be neglected (36) on the polyvinyl chloride (PVC) or Silastic surfaces, then this study's albumin coverage on the substrates can be taken as follows: (a) polystyrene, 97\% coverage; (b) PVC, 77\% coverage; (c) Silastic, 86\% coverage; and (d) Biomer, $100 \%$ coverage. Adsorption of albumin to a lesser extent on polyurethanes or polystyrenes under similar conditions has also been shown elsewhere (45).

The isotherms of iodine-labeled fibrinogen (Fg) are shown in Fig. 3. The adsorption values are similar to those reported in the literature $(45,51)$ and the similar lack of a saturated monolayer on the surface at these concentrations is well depicted. Monolayer coverage is reported to be in the range of 0.8 to $1.2 \mu \mathrm{g} /$ $\mathrm{cm}^{2}$ for $\mathrm{Fg}$. If a $1.0 \mu \mathrm{g} / \mathrm{cm}^{2}$ coverage is taken as $100 \%$ monolayer coverage, then the percentage coverage of Fg on these substrates can be given as: (a) polystyrene, 59\%; (b) PVC, 79\%; (c) Silastic, 59\%; and (d) Biomer, 59\%.

Iodine-labeled fibronectin (Fn) adsorption isotherms are given in Fig. 4 for the polymeric substrates and hydrophilic silica. The values listed are comparable to those given in the literature (52-60) using similar concentrations. Except for the complete isotherms given by Bornzin and Miller (50), much of the adsorption work has ignored the possibilities of preferential adsorption of labeled Fn and/or the air-solution interface. These problems, in addition to incompletely characterized substrates, results in a large uncertainty as to actual monolayer coverage values. Therefore, the values of Fig. 4 will be assumed to be $100 \%$ monolayer coverage, since no preferential adsorption was seen to occur in this study. The large difference in plateau values of the sub- 
(a)

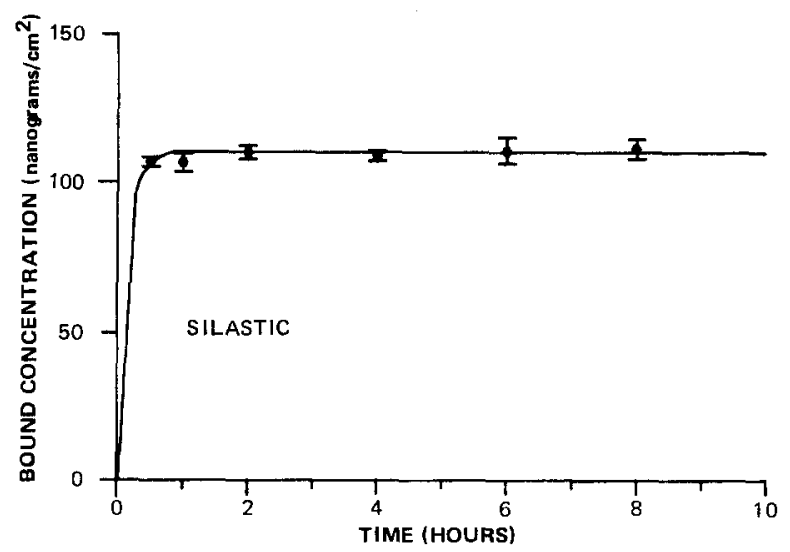

(b)

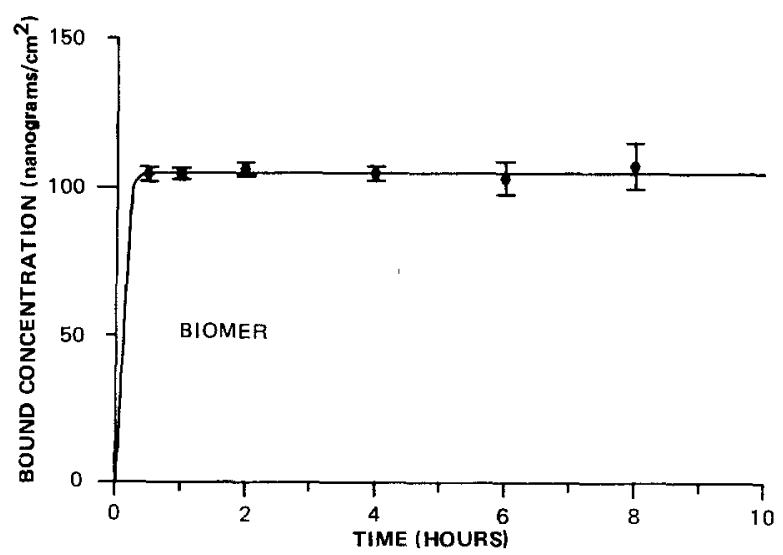

(c)

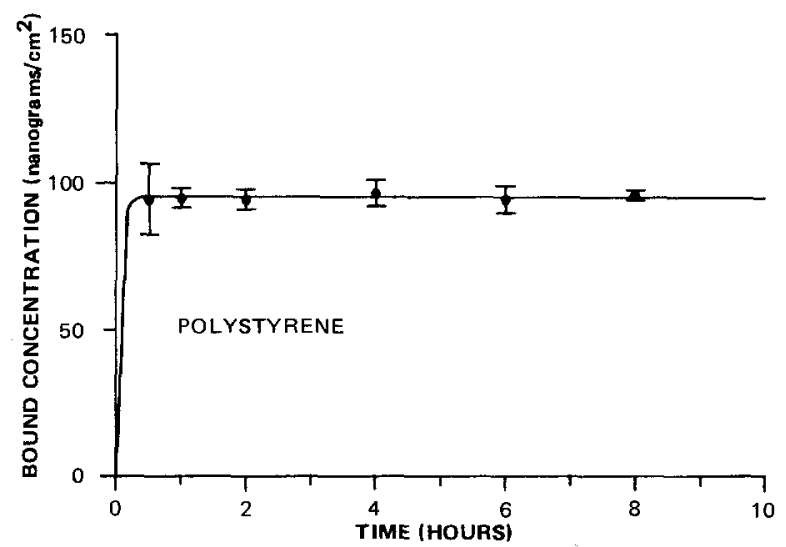

FIG. 7. ${ }^{14} \mathrm{C}$-Labeled heparin binding to adsorbed fibronectin disks. Values given are mean $\pm \operatorname{SD}(n=3)$.

(a) Biomer, (b)-Silastic, (c) PS, (d) PVC, (e) hydrophilic glass.

strates, as compared to PVC, could be explained by the occurrence of a conformational change in Fn upon adsorption onto PVC (dis- cussed below). This accommodation of Fn increases the total amount of Fn present on the PVC surface. Such a change was reported ear- 
(d)

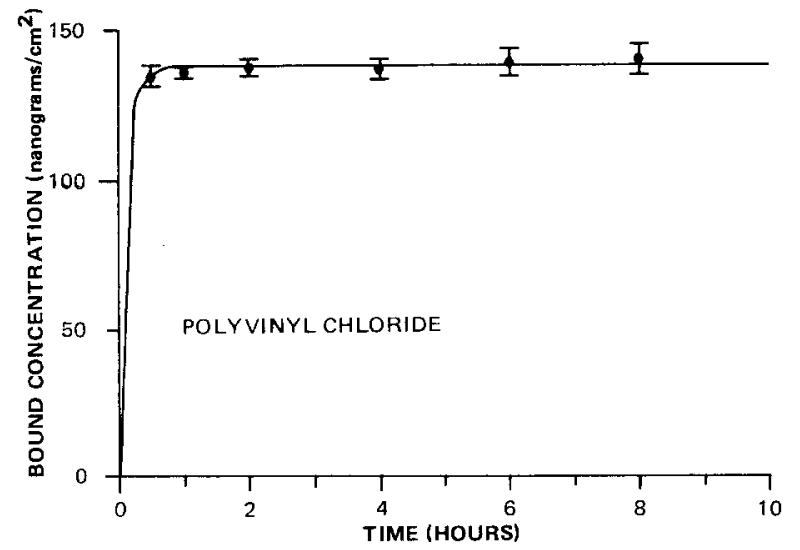

(e)

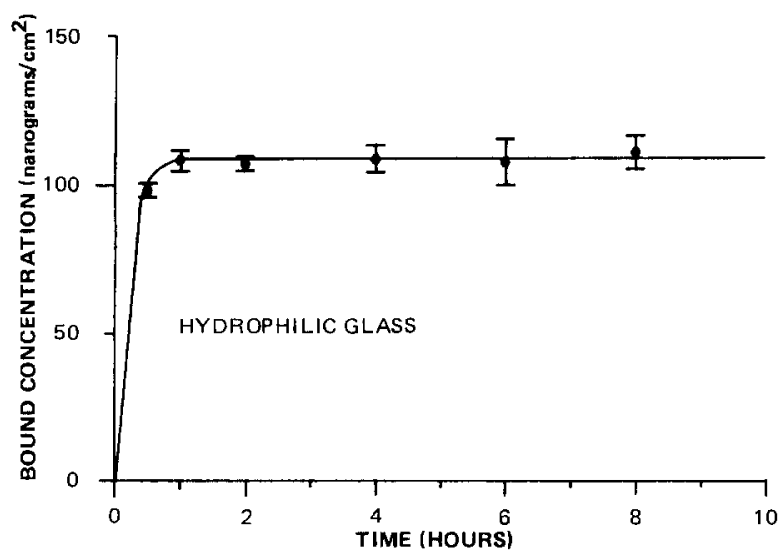

FIG. 7-Continued.

lier for Fn adsorption onto hydrophobic silica surface $(53,61)$.

Figure 5 shows kinetics of adsorption for ${ }^{125}$ I-Fn. In all cases steady-state values were reached within $2 \mathrm{~h}$, except for hydrophilic silica and within $1 \mathrm{~h}$ for adsorption onto PVC. ${ }^{125}$ I-Fn adsorption onto PVC can be fit to an ideally controlled process by diffusion, for the first $30 \mathrm{~min}$. Thereafter, for the next 5 to 7 min a change in the type of adsorption was seen and then the onset of steady state followed. This pattern was quite similar to the pattern observed in the total internal reflection fluorescence (TIRF) mode for hydrophobic NPS-silica except for the concentration of Fn adsorbed under those conditions was calculated to be much less (61). In the TIRF mode, the Fn adsorbed onto the hydrophobic silica was observed to be in a different environment (conformation) than that on the hydrophilic silica. It was thus hypothesized that this conformational change accounted for the increased accommodation of Fn on the hydrophobic silica surface. It is probable then that the differences in the adsorption rate and concentration of Fn on PVC, as compared to the other substrates was due to it also being in a different conformation on that substrate. It is interesting to note that the adsorption kinetics of ${ }^{125}$ I-labeled Fn onto hydrophilic silica appears very similar to the second time phase of the TIRF monitoring of Fn adsorption on the same surface (61). The static adsorption seemed to take longer; however, this was not 


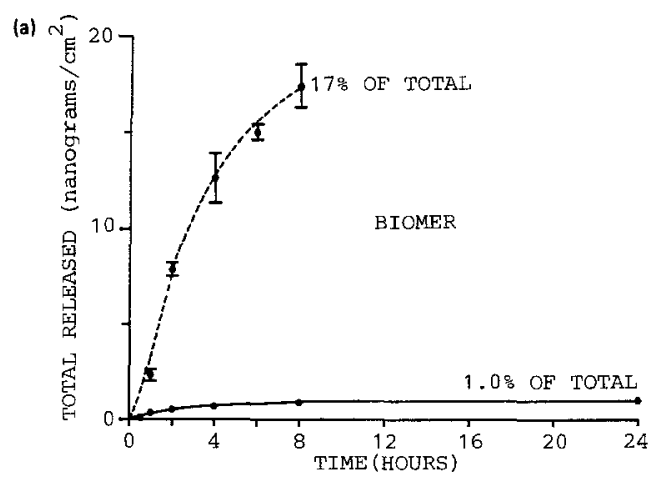

(b)
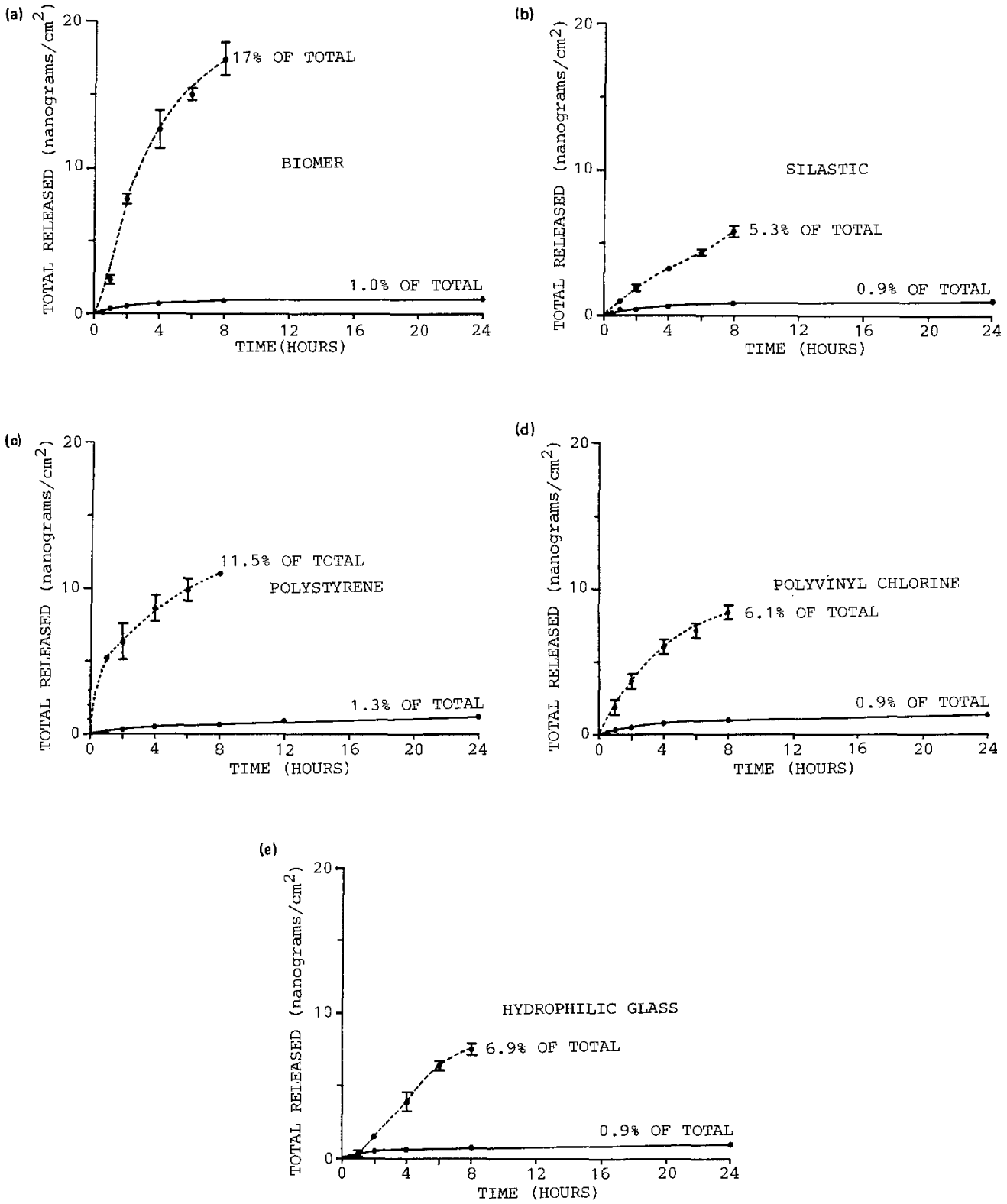

FIG. 8. Release of ${ }^{14} \mathrm{C}$-labeled heparin from fibronectin-coated disks. Dashed line is release in plasma and solid line is release in PBS buffer. Values given are mean \pm SD ( $n=3)$. (a) Biomer, (b) Silastic, (c) PS, (d) PVC, (e) hydrophilic glass.

unexpected since no flow or turbulent convection were occurring in the static cell which would aid in mass transport to the surface or through the diffusional boundary layer. These static adsorption kinetics were very similar to those reported in the literature for monitoring Fn adsorption by TIRF under static conditions (62).

It is tempting to say that most of the static adsorption processes depicted here deviate 
TABLE IV

Protein Stability and Heparin Binding Stability to Adsorbed Proteins

\begin{tabular}{|c|c|c|c|c|c|c|c|c|c|}
\hline \multirow[b]{2}{*}{$\begin{array}{l}\text { Protein and } \\
\text { substrate }\end{array}$} & \multicolumn{2}{|c|}{$\begin{array}{c}\text { Concentration of } \\
\text { bound heparin } \\
\left(\mu \mathrm{g} / \mathrm{cm}^{2}\right)\end{array}$} & \multirow[b]{2}{*}{$\begin{array}{l}\text { Concentration of } \\
\text { adsorbed protein } \\
\left(\mu \mathrm{g} / \mathrm{cm}^{2}\right)\end{array}$} & \multicolumn{2}{|c|}{$\begin{array}{l}\text { Molar ratio: } \\
\text { heparin to protein }\end{array}$} & \multicolumn{2}{|c|}{$\begin{array}{l}\text { Release in PBS } \\
(24 \mathrm{~h}), \%\end{array}$} & \multicolumn{2}{|c|}{$\begin{array}{l}\text { Release in plasma } \\
\qquad(8 \mathrm{~h}), \%\end{array}$} \\
\hline & $\begin{array}{l}\text { solition } \\
\text { depletion } \\
\text { technique }\end{array}$ & $\begin{array}{l}\text { Ionization } \\
\text { technique }\end{array}$ & & $\begin{array}{l}\text { depletion } \\
\text { technique }\end{array}$ & $\begin{array}{l}\text { Ionization } \\
\text { technique }\end{array}$ & Protein & Heparin & Protein & Heparin \\
\hline \multicolumn{10}{|l|}{ Fn } \\
\hline Silastic & 0.11 & 0.11 & 0.35 & $5.8: 1.0$ & $5.8: 1.0$ & 12 & $0.9 \%$ & & $5.3 \%$ \\
\hline PS & 0.10 & 0.09 & 0.31 & $6.0: 1.0$ & $5.5: 1.0$ & 18 & $1.3 \%$ & 16 & $11.5 \%$ \\
\hline PVC & 0.14 & 0.15 & 1.68 & $1.5: 1.0$ & $1.6: 1.0$ & 65 & $0.9 \%$ & 8 & $6.1 \%$ \\
\hline Biomer & 0.11 & 0.11 & 0.34 & $5.5: 1.0$ & $6.0: 1.0$ & 10 & $1.0 \%$ & 47 & $17.0 \%$ \\
\hline Hydrophilic & & & & & & & & 10 & \\
\hline Silica & 0.11 & - & 0.30 & $6.6: 1.0$ & - & 10 & $0.9 \%$ & 15 & $6.9 \%$ \\
\hline \multicolumn{10}{|l|}{$\mathrm{Fg}$} \\
\hline Silastic & 0 & - & 0.59 & $0: 1$ & 一 & 14 & - & 61 & - \\
\hline PS & 0 & - & 0.59 & $0: 1$ & - & 7 & - & 6 & - \\
\hline PVC & 0 & - & 0.79 & $0: 1$ & - & 22 & - & 12 & - \\
\hline Biomer & 0 & - & 0.64 & $0: 1$ & 一 & 15 & - & 21 & - \\
\hline \multicolumn{10}{|l|}{ Albumin } \\
\hline Silastic & 0 & 0 & 0.60 & $0: 1$ & $0: 1$ & 18 & - & 63 & - \\
\hline PS & 0 & 0 & 0.68 & $0: 1$ & $0: 1$ & 22 & - & 38 & - \\
\hline PVC & 0 & 0 & 0.52 & $0: 1$ & $0: 1$ & 12 & - & 20 & - \\
\hline Biomer & 0 & 0 & 0.84 & $0: 1$ & $0: 1$ & 15 & - & 22 & - \\
\hline
\end{tabular}

${ }^{a}$ Data derived from Figs. 1-8.

from an ideal diffusion-controlled process. This cannot be said for certain, however, since the first samples were taken (experiments terminated) after $15 \mathrm{~min}$ of adsorption time. It is probable that diffusion does have a part in the very early stages of the adsorption process (63) only it was not observed here due to the sampling protocols.

Desorption of adsorbed ${ }^{125} \mathrm{I}-\mathrm{Fn}$ monolayer films is shown in Fig. 6 in buffer and plasma solutions. The monolayers were adsorbed from $0.3 \mathrm{mg} / \mathrm{ml}$ solutions of radiolabeled protein. Fibronectin shows significant losses on PVC surfaces with both PBS and plasma. However, the other surfaces show only a 10 to $15 \%$ loss in PBS and plasma.

The adsorbed Fn generally appears quite stable. The PVC, however, shows FN monolayer losses of $40 \%$ in plasma and $60 \%$ in PBS buffer. This is due perhaps to the nature of the adsorption process. Adsorbing quite rapidly (diffusion controlled), the protein may be in a conformation that is a steady-state equilibrium with the Fn "sink," yet not in a preferred orientation. Under desorption conditions, this steady-state condition is no longer the equilibrium state and thus the surface concentration is reduced considerably possibly to accommodate reorientation.

The kinetics of binding and release of ${ }^{14} \mathrm{C}$ labeled heparin with Fn-coated substrates are shown in Figs. 7 and 8, respectively. ${ }^{14} \mathrm{C}$-heparin solutions were not observed to be significantly depleted when passed over columns preadsorbed with monocomponent fibrinogen and albumin solutions, over the same period of time (36).

The kinetics of binding for adsorbed fibronectin (see Fig. 7) show that steady state occurred in all cases within $1 \mathrm{~h}$. The concentra- 
TABLE V

APTT Assay for Heparin Activity on Fn-Coated Disks

\begin{tabular}{llccc}
\hline Substrate & \multicolumn{1}{c}{ Heparin } & $\begin{array}{c}\text { Rel. units } \\
\text { activity of heparin }\end{array}$ & $\begin{array}{c}\text { Time } \\
(\mathrm{s})\end{array}$ & $\begin{array}{c}\text { Equivalent concentration } \\
\text { of heparin }^{b} \\
\left(\mu \mathrm{g} / \mathrm{cm}^{2}\right)\end{array}$ \\
\hline Silastic & None $(n=3)$ & $a$ & $11.4 \pm 0.7$ & $a$ \\
& LMW $(n=3)$ & 0.03 & $24.5 \pm 3.9$ & 0.18 \\
& HMW $(n=3)$ & 0.02 & $23.6 \pm 1.7$ & 0.12 \\
Begular $(n=3)$ & 0.02 & $23.5 \pm 2.9$ & 0.12 \\
Biomer & None $(n=3)$ & $a$ & $32.0 \pm 6.9$ & $a$ \\
& LMW $(n=3)$ & 0.03 & $45.3 \pm 11.4$ & 0.18 \\
& HMW $(n=3)$ & 0.02 & $44.4 \pm 13.1$ & 0.12 \\
PS & Regular $(n=3)$ & 0.03 & $44.7 \pm 8.1$ & 0.18 \\
& None $(n=3)$ & $a$ & $16.2 \pm 2.5$ & $a$ \\
& LMW $(n=3)$ & 0.03 & $29.5 \pm 4.7$ & 0.18 \\
& HMW $(n=3)$ & 0.02 & $27.8 \pm 4.7$ & 0.12 \\
PVC & Regular $(n=3)$ & 0.03 & $28.7 \pm 3.6$ & 0.18 \\
& None $(n=3)$ & $a$ & $14.1 \pm 0.3$ & $a$ \\
& LMW $(n=3)$ & 0.05 & $27.9 \pm 5.5$ & 0.30 \\
& HMW $(n=3)$ & 0.04 & $26.0 \pm 2.2$ & 0.24 \\
Human plasma-coated biomer & Regular $(n=3)$ & 0.05 & $27.4 \pm 1.9$ & 0.30 \\
\hline
\end{tabular}

${ }^{a}$ Taken as zero.

${ }^{b}$ Assuming 165 units/mg heparin.

tions of ${ }^{14} \mathrm{C}$-heparin bound to the adsorbed fibronectin were approximately 90 to $150 \mathrm{ng}$ per square centimeter area. It is interesting to note that the "steady-state" results in a fairly straight line with a positive slope, when fit by linear regression. The slopes vary from 0.14 to 0.35 . Glass, Biomer, and polystyrene all had constant steady-state slopes of approximately 0.25 while Silastic and PVC had slopes of 0.14 and 0.35 , respectively. It seems that since Fn desorbs from all of these substrates that more scatter would be seen using a technique that measures the solution protein depletion, due to protein adsorption, and the concurrent protein desorption from the same substrate. However, this was not observed. It remains to be elucidated whether the binding of heparin to fibronectin changes the sticking coefficient of fibronectin by allosteric binding of the ligand.

Figure 8 shows the release of bound ${ }^{14} \mathrm{C}$ heparin in PBS buffer and plasma. In all systems, the total amount of released heparin did not equal that predicted by Eq. [3], which accounts only for released protein (see Fig. 6). This may be explained by several possible mechanisms of which two are discussed: (a) heparin binding to adsorbed fibronectin alters the adsorbed protein sticking coefficient thus making it adhere more tenaciously to the various substrates. Perhaps by allosterically binding heparin to the adsorbed protein, the resulting conformational change in the protein gives it a better "foot hold" on the substrate surface. This allosteric change in Fn induced by the binding of heparin has been suggested $(64,65)$ for the mechanism by which fibronectin increases its ability to bind to immobilized collagen and complex solution phase collagen; (b) solution-bound heparin may be released more readily and reorientation of the protein monolayer may accommodate the rebinding of the free heparin. This mechanism seems feasible for the PVC surface where Fn is apparently sterically hindered due to the high concentration of surface adsorbed $F n$ in 


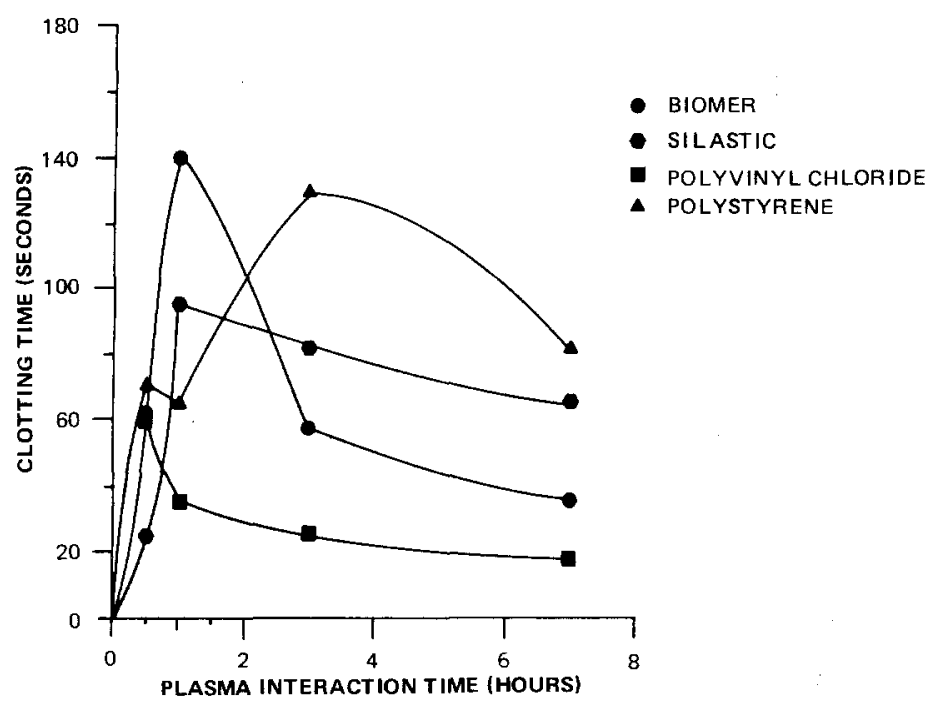

FIG. 9. Activated partial thromboplastin times on column controls. The columns were preadsorbed with native fibronectin only. The values given are means. The standard deviations were approximately \pm 50 to $100 \mathrm{~s}$.

comparison with other substrates; however, it is less likely for the other surfaces where the absorbed Fn is apparently more "spread out."

In all cases, no more than $2 \%$ of the total ${ }^{14} \mathrm{C}$-heparin was released in PBS buffer and no more than $17 \%$ of the total ${ }^{14} \mathrm{C}$-heparin was released in the plasma environment. The great increase in the plasma release of ${ }^{14} \mathrm{C}$-heparin was probably due to the binding of heparin to blood factors rendering them inactive, and to the bacteriological and enzymatic attack of the protein monolayer or bound heparin. Exchange of the adsorbed protein in plasma could also increase the amount of released heparin in a bound state to the original protein.

The results of ${ }^{14} \mathrm{C}$-heparin binding protein monolayers as determined by gas ionization counting of the ${ }^{14} \mathrm{C}$-label are given in Table IV. For ease of comparison, the tabulated results from Figs. 2 through 8 are also given. All six binding sites for heparin on fibronectin, as determined by Scatchard analysis, were active and available in the adsorbed state for all substrates except PVC. The increased concentration of Fn adsorbed onto the PVC surfaces or its resultant different adsorbed conformation
$(64,65)$ probably sterically blocked the majority of the binding sites in that system. It appears that two heparin binding sites are hindered on both sides of the protein dimer and that a third may be hindered somewhat on one of the sides. Most likely, energy supplied by thermal fluctuations or convective turbulence probably renders this one semihindered site somewhat available for heparin binding. This explains the molar ratio of one fibronectin to approximately 1.5 heparin molecules.

${ }^{14} \mathrm{C}$-Heparin binding to the proteinaceous monolayer left after human serum interaction was not observed (36). In columns with surface areas up to $100 \mathrm{~cm}^{2}$, the introduced ${ }^{14} \mathrm{C}$-heparin solution did not decrease in activity over a $24-h$ period. Assuming that the protein monolayer is at least as stable as a composite of the aforementioned monocomponent systems (Table IV) of albumin, fibrinogen, and fibronectin in PBS (pH 7.4), the possibility of total protein desorption and thus undetected solution binding can be eliminated. After buffer flush, desorption/release was carried out in a buffer environment for $24 \mathrm{~h}$ or in a canine plasma environment for $8 \mathrm{~h}$. All samples were 
(a)

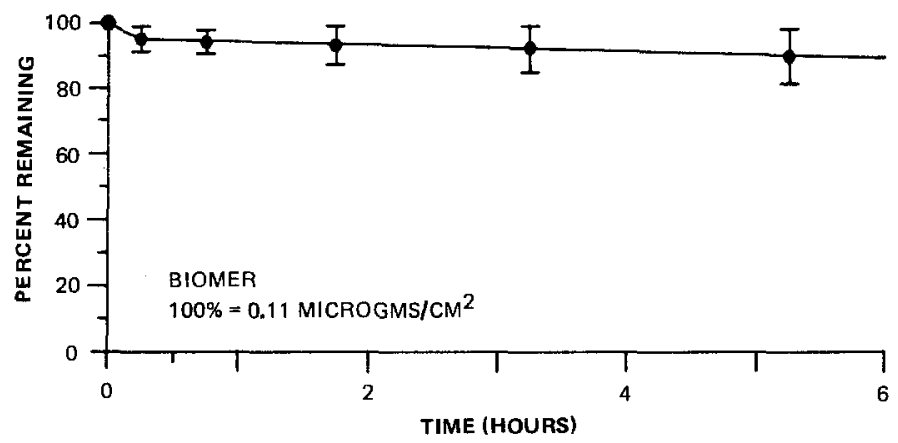

(b)

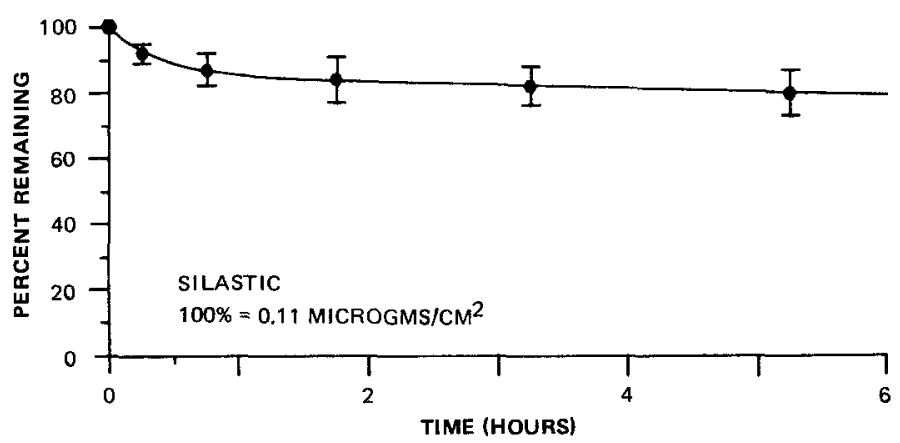

(c)

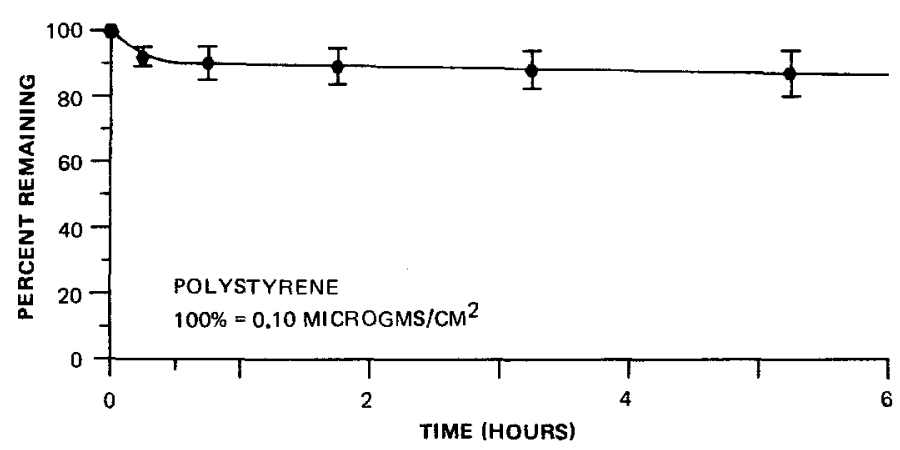

(d)

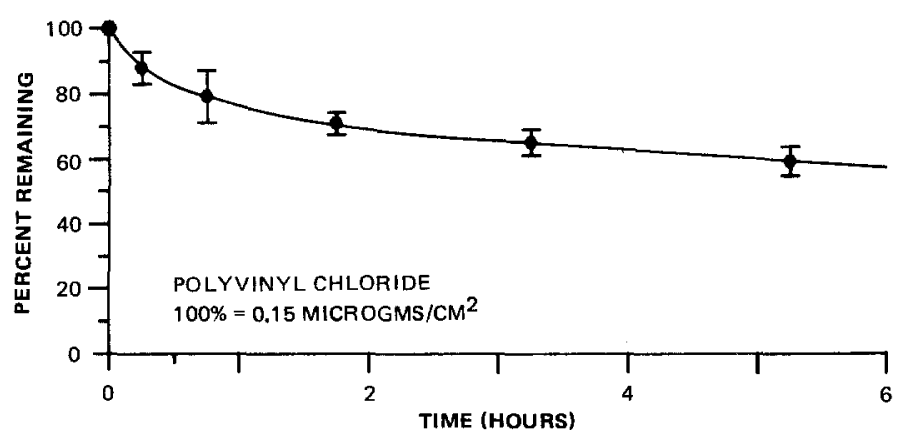

FIG. 10. Factor $\mathrm{X}_{\mathrm{a}}$ assay for heparin released in plasma for column type adsorption. Values given are mean $\pm \mathrm{SD}(n=3$ ). (a) Biomer, (b) Silastic, (c) PS, (d) PVC, (e) hydrophilic glass. 
(e)

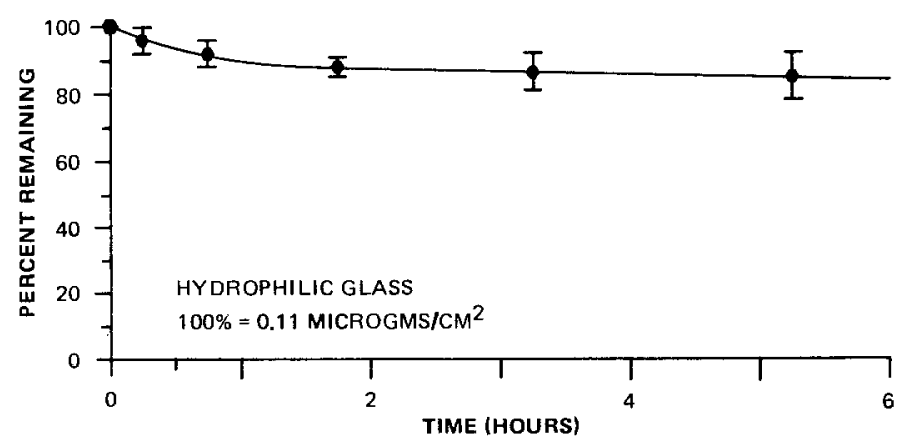

FIG. 10-Continued.

equivalent to background counts or within the error of the standard deviation. Thus, it may be concluded that the proteinaceous monolayer cannot bind heparin and, therefore, must contain very little fibronectin or inhibited fibronectin which is unable to bind heparins.

Activated partial thromboplastin time (APTT) assays for heparin are generally considered valuable; however, they are nonspecific in nature $(66,67)$ in that: (a) bound heparin and solution heparin may be treated equivalently and (b) any adsorption, and thus loss, of coagulation factors will prolong the resultant assay time. The results of APTT coagulation times done on plasma that had been in contact with polymer substrate discs, pretreated with adsorbed Fn and bound heparin fractions, are given in Table V. The assay showed generally that all the prebound heparin was available for prolongation of coagulation times. The excessive prolongation of some observed clotting times is probably due to the depletion of coagulation factors (68). The depletion of these factors could occur by adsorption to container or substrate surfaces or inactivation by binding to either adsorbed or desorbed Fn molecules. If loss of coagulation factors were causing excessively prolongated coagulation times not accounted for by the heparin present, it would be magnified in systems with much larger surface areas. Figure 9 shows prolongation of clotting times with increasing plasma contact time on column con- trol substrates preadsorbed only with fibronectin. The erratic behavior can be explained by the binding or adsorption and subsequent release or desorption with time, of coagulation factors. This behavior caused the scatter (SD) of times to be so great that the coagulation times could not be distinguished from those of the column substrate controls. Therefore, to determine the increase in coagulation times attributable to the bound and released heparin from the column experiments, heparin colorimetric assays run concurrently or at the end of the plasma incubation of the substrate columns had to be done.

Activated Factor $\mathrm{X}$ assay is very sensitive and specific for heparin in plasma environments (34). The method involves the use of a chromogenic substrate (S2222) that is susceptible to the presence of $X_{a}$. Unknown concentrations of heparin are introduced which bind to known quantities of $\mathrm{X}_{\mathrm{a}}$. The $\mathrm{X}_{\mathrm{a}}$-heparin complex is inactive toward the $\mathrm{S} 2222$ substrate. The remaining $X_{a}$ activity is quantitated by amidolysis of the $\mathbf{S} 2222$ substrate. The amidolysis is stopped by the addition of acetic acid after a specified time. This methodology can detect 0.02 units of heparin per milliliter of plasma tested.

Concurrent with APTT testing of plasma subjected to column substrates, each sample was tested, in duplicate, for released heparin activity via activated Factor $X$ assay. The results are given in Fig. 10 (also reference Table 
IV and Fig. 8). The results correlated well with the data observed for heparin release in plasma. Small differences in the amounts of heparin released may be due to the different plasmas utilized in the two studies (bovine versus canine).

\section{CONCLUSIONS}

This in vitro study has shown several important aspects relating to localized heparin delivery at a foreign surface-blood interface. First, albumin, albeit a carrier of metabolic by-products and some anticoagulants, does not bind heparin at physiological $\mathrm{pH}$ in solution or in the adsorbed state. The same can be stated for fibrinogen. Plasma fibronectin, on the other hand, binds heparin in either state. Fibronectin was shown to have six binding sites for heparin which may be sterically blocked if fibronectin adsorbs in such a fashion as to increase the surface concentration of the adsorbed protein. Next, it has been shown that by using adsorbed fibronectin as an intermediate, it is possible to deliver heparin, prebound to the adsorbed protein, in concentrations up to approximately $0.2 \mu \mathrm{g} / \mathrm{cm}^{2}$ in a plasma environment. Also, active surfacebound heparin was maintained at approximately 83 to $99 \%$ of original-bound heparin concentrations for up to 6 to $8 \mathrm{~h}$ time. The stability of the Fn monolayer was increased by the binding of heparin, probably due to an allosteric change upon binding the drug moiety, increasing the sticking coefficient of Fn $(64,65)$.

It is also interesting to note that human serum, allowed to adsorb onto Biomer surfaces, does not bind heparin even though fibronectin occurs in most healthy adults in the range of 300 to $500 \mu \mathrm{g} / \mathrm{ml}$ plasma. Therefore, Fn appears not to be preferentially adsorbed from multicomponent systems. Or, if it is, it adsorbs from such systems in conformations unable to bind heparin. Comparing APTT results of the fibronectin-precoated substrates bound to heparin, to controls precoated with human plasma or fibronectin alone, showed that the fibronectin-heparin surface does not increase the intrinsic activation of the coagulation cascade but rather increases the relative normal coagulation times two to three times over those observed with monocomponent human plasma or fibronectin. When the APTT results of this fibronectin-heparin complex are compared to the albumin-heparin covalent conjugate $(7,18-21)$, it can be seen that the times are similar, indicating that both are effective in prolonging clotting times. However, the comparison of direct times is not the important factor; rather that both tend to double or triple their clotting times relative to controls is significant.

The trends observed throughout this section seem to indicate that the bound heparin is active in prolonging clotting times (APTT and $\mathrm{X}_{\mathrm{a}}$ assays) and that the fibronectin adsorbed monolayer may indeed aid in reducing the intrinsic activation of Factor XII. Furthermore, the amount of heparin remaining bound to the monolayer is greater than predicted by protein desorption alone.

\section{ACKNOWLEDGMENTS}

The generous gift of human plasma fibronectin from Dr. Deane F. Mosher was greatly appreciated. The study was funded by NIH Grant HL-17623-10.

\section{REFERENCES}

1. Salzman, E. W., Blood 38, 509 (1971).

2. Forbes, C. D., and Prentice, C. R., Brit. Med. Bull. 34, 201 (1978).

3. Lyman, D. J., Brash, J. L., Chaikin, S. W., Klein, K. G., and Carini, M., Trans. Amer. Soc. Artif. Intern. Organs 14, 250 (1968).

4. Lyman, D. J., in "Structural Order in Polymers" (F. Cierdelli and P. Gusti, Eds.), pp. 205-220. Pergamon, Oxford, 1981.

5. Young, B. R., Lambrecht, L. K., Cooper, S. L., and Mosher, D. F., "Biomaterials: Interfacial Phenomena and Applications," Vol. 199, pp. 317-350. Advances in Chemistry Series, Amer. Chem. Soc., Washington, D.C., 1982.

6. Lee, E. S., and Kim, S. W., Trans. Amer. Soc. Artif. Intern. Organs 25, 124 (1979).

7. Hennink, W. E., Dost, L., Feijen, J., and Kim, S. W., 
Trans. Amer. Soc. Artif. Intern. Organs 29, 200 (1983).

8. Lee, R. G., and Kim, S. W., J. Biomed. Mater. Res. 8, 393 (1983).

9. Horbett, T. A., Adv. Chem. Ser. 199, 233 (1983).

10. Munro, M. S., Quattrone, A. J., Ellsworth, S. R., Kulkarni, P., and Eberhart, R. C., Trans. Amer. Soc. Artif. Intern. Organs 27, 499 (1981).

11. Kim, S. W., and Lee, R. G., "Adsorption of Blood Proteins onto Polymer Surfaces," Vol. 145, pp. 218-229. Advances in Chemistry Series, Amer. Chem. Soc., Washington, D.C., 1975.

12. Stoner, G. E., Srinivasan, S., and Gileadi, E., J. Phys. Chem. 75, 2107 (1971).

13. Ihlenfeld, J. V., and Cooper, S. L., J. Biomed. Mater. Res. 13, 577 (1979).

14. Lee, R. G., Adamson, C., and Kim, S. W., Thromb. Res. 4, 485 (1974).

15. Brash, J. L., and Davidson, V. J., Thromb. Res. 9, 249 (1976).

16. Kim, S. W., Ebert, C. D., Lin, J. Y., and McRea, J. C., Amer. Soc. Artif. Intern. Organs 6, 76 (1983).

17. Kim, H. P., Byon, S. M., Yeom, Y. I., and Kim, S. W., J. Pharm. Sci. 72, 225 (1983).

18. Hennink, W. E., Feijen, J., Ebert, C. D., and Kim, S. W., Thromb. Res. 29, 1 (1983).

19. Hennink, W. E., Ebert, C. D., Kim, S. W., Breemhar, W., Bantjes, A., and Feijen, J., Biomaterials 5, 264 (1984).

20. Hennink, W. E., Kim, S. W., and Feijen, J., J. Biomed. Mater. Res. 18, 911 (1984).

21. Hennink, W. E., Dost, L., Van Hken, W. G., Kim, S. W., and Feijen, J., "Biomaterials and Artificial Organs," Symposium at Strathclyde, U.K., in press.

22. "Guidelines for Physicochemical Characterization of Biomaterials," U.S. Department of Health and Human Services, NIH Publication No. 80-2186, September 1980.

23. Coleman, D. L., Atwood, A. I., and Andrade, J. D., J. Bioeng. 1, 33 (1976).

24. King, R. N., Andrade, J. D., Ma, S. M., Gregonis, D. E., and Brostrom, L. R., in "Fundamentals of Interfacial Phenomena: Research Needs and Priorities" (J. Bers, Ed.). Proceedings of the National Science Foundation Workshop, Seattle, Washington, 1979.

25. Haller, I., J. Amer. Chem. Soc. 100, 8050 (1978).

26. Brier-Russell, D., Salzman, E. W., Lindon, J., Hendin, R., Merrill, E. W., Dincer, A. K., and Wu, J. S., J. Colloid Interface Sci. 81, 311 (1981).

27. Ogston, D., and Bennett, B., "Haemostasis: Biochemistry, Physiology and Pathology." Wiley, New York, 1977.

28. Gregonis, D. E., Hsu, R., Buerger, D. E., Smith, L. K., and Andrade, J. D., in "Macromolecular
Solution" (R. B. Seymour and G. A. Stahl, Eds.), pp. 120-133. Pergamon, New York, 1982.

29. Andrade, J. D., Gregonis, D. E., and Smith, L. M., "Physiochemical Aspects of Polymer Surfaces." Plenum, New York, 1982.

30. Hurst, R. E., Van Dedem, G., and Settine, J. M., Thromb. Res. 22, 633 (1981).

31. Rice, R. H., and Mean, G. E., J. Biol. Chem. 246, 831 (1979).

32. Jentoff, N., and Dearborn, D. G., J. Biol. Chem. 254, 4359 (1979).

33. McNamara, P. J., and Bogardus, J. B., J. Pharm. Sci. 71, 1066 (1982).

34. Teien, A. N., Lie, M., and Abildgaard, U., Thromb. Res. 8, 413 (1976).

35. Scatchard, G., Ann. N.Y. Acad. Sci. 51, 660 (1949).

36. Winterton, L. C., "Control of Initial Events in Surface Thrombosis by Protein-Heparin Complexes," Ph.D. dissertation. University of Utah, Salt Lake City, Utah, 1985.

37. Mosher, D. F., Ann. Rev. Med. 35, 561 (1984).

38. Ruoslahti, E., Hayman, E. G., Perishcbacher, M., and Engvall, E., "Methods in Enzymology" (L. W. Cunningham and D. W. Frederiksen, Eds.), Vol. 82, pp. 803-831. Academic Press, New York, 1982.

39. Yamada, K. M., in "The Glycoconjugates" (M. I. Horowitz and W. Pigman, Eds.), Vol. 3. Academic Press, New York, 1982.

40. Peterson, T. E., Thorgersen, H. C., Skorstengaard, K., Vibe-Peterson, K., Sottrup-Jensen, L., and Magnusson, S., Proc. Natl. Acad. Sci. (USA) 80, 137 (1983).

41. Skorstengaard, K., Thorgersen, H. C., and Peterson, T. E., Eur. J. Biochem. 140, 235 (1984).

42. Grant, W. H., Smith, L. E., and Stromberg, R. T., J. Biomed. Mater. Res. Symp. 8, 33 (1977).

43. Van der Scheer, A., Feijen, J., Elhorst, J. K., Krugers Dagneaus, P. G. L. C., and Smolders, C. A., J. Colloid Interface Sci. 66, 136 (1978).

44. Horbett, T. A., J. Biomed. Mater. Res. 15, 673 (1981).

45. Brash, J. L., and Uniyal, S., J. Polym. Sci., Polym. Symp. 66, 377 (1979).

46. Feijen, J., data to be published.

47. Morrissey, B. W., Ann. N.Y. Acad. Sci. 283, 50 (1982).

48. Soderquist, M. E., and Walton, A. G., J. Colloid Interface Sci. 75, 386 (1980).

49. MacRitchie, F., in "Advances in Protein Chemistry" (C. B. Anfinsen, M. L. Anson, J. T. Edsall, and F. M. Richards, Eds.), Vol. 32, pp. 283-326. Academic Press, New York, 1978.

50. Bornzin, G. A., and Miller, I. F., I. Colloid Interface Sci. 86, 539 (1982).

51. Elhorst, J. K., Olthuis, F. M. F. G., Bargeman, D., Smolder, C. A., and Feijen, J., Int. J. Artif. Organs 1, 288 (1978). 
52. Grinnell, F., and Feld, M. K., J. Biol. Chem. 257, 4888 (1982).

53. Grinnell, F., and Feld, M. K., J. Biomed. Mater. Res. 15, 363 (1981).

54. Jonsson, U., Ivarsson, B., and Berghem, L., J. Colloid Interface Sci. 90, 148 (1982).

55. Adams, G. A., and Feuerstein, I. A., Trans. Amer. Soc. Artif. Intern. Organs 27, 219 (1981).

56. Koltisko, B. M., Jr., "Chromotographic Analysis of Protein Adsorption," M.S. thesis. Case Western Reserve University (1981).

57. Hughes, R. C., Pena, S. D. J., Clark, J., and Dourmashkin, R. R., Exp. Cell Res. 121, 307 (1979).

58. Klebe, R. J., Bentley, K. L., and Schoen, R. C., J. Cell. Physiol. 109, 481 (1981).

59. Haas, R., and Culp, L. A., J. Cell. Physiol. 113, 289 (1982).

60. Young, B. R., Lambrecht, L. K., Cooper, S. L., and Mosher, D. F., in "Biomaterials: Interfacial Phenomena and Applications" (S. L. Cooper and N. A. Peppas, Eds.), Vol. 199. Advances in Chem- istry Series, Amer. Chem. Soc., Washington, D.C., 1982.

61. Iwamoto, G. K., Winterton, L. C., Stoker, R. S., Van Wagonen, R. A., Andrade, J. D., and Mosher, D. F., J. Colloid Interface Sci. 106, 459 (1985).

62. Iwamoto, G. K., Van Wagonen, R. A., and Andrade, J. D., J. Colloid Interface Sci. 86, 581 (1982).

63. Van Dulm, P., and Norde, W., J. Colloid Interface Sci. 91, 248 (1983).

64. Johansson, S., and Hook, M., Biochernistry J. 187, 521 (1980).

65. Jilek, F., and Hormann, H., Hoppe-Seylers' Z. Physiol. Chem. 360, 597 (1979).

66. Stathakis, N. E., and Mosesson, M. W., J. Clin. Invest. 60, 855 (1977).

67. Teien, A. N., and Abildgaard, U., Thromb. Haemostasis 35, 592 (1976).

68. Merrill, E. W., Salzman, E. W., Wory, P. S. L., Ashford, T. P., Brown, A. H., and Austen, W. G., J. Appl. Physiol. 29, 723 (1970). 